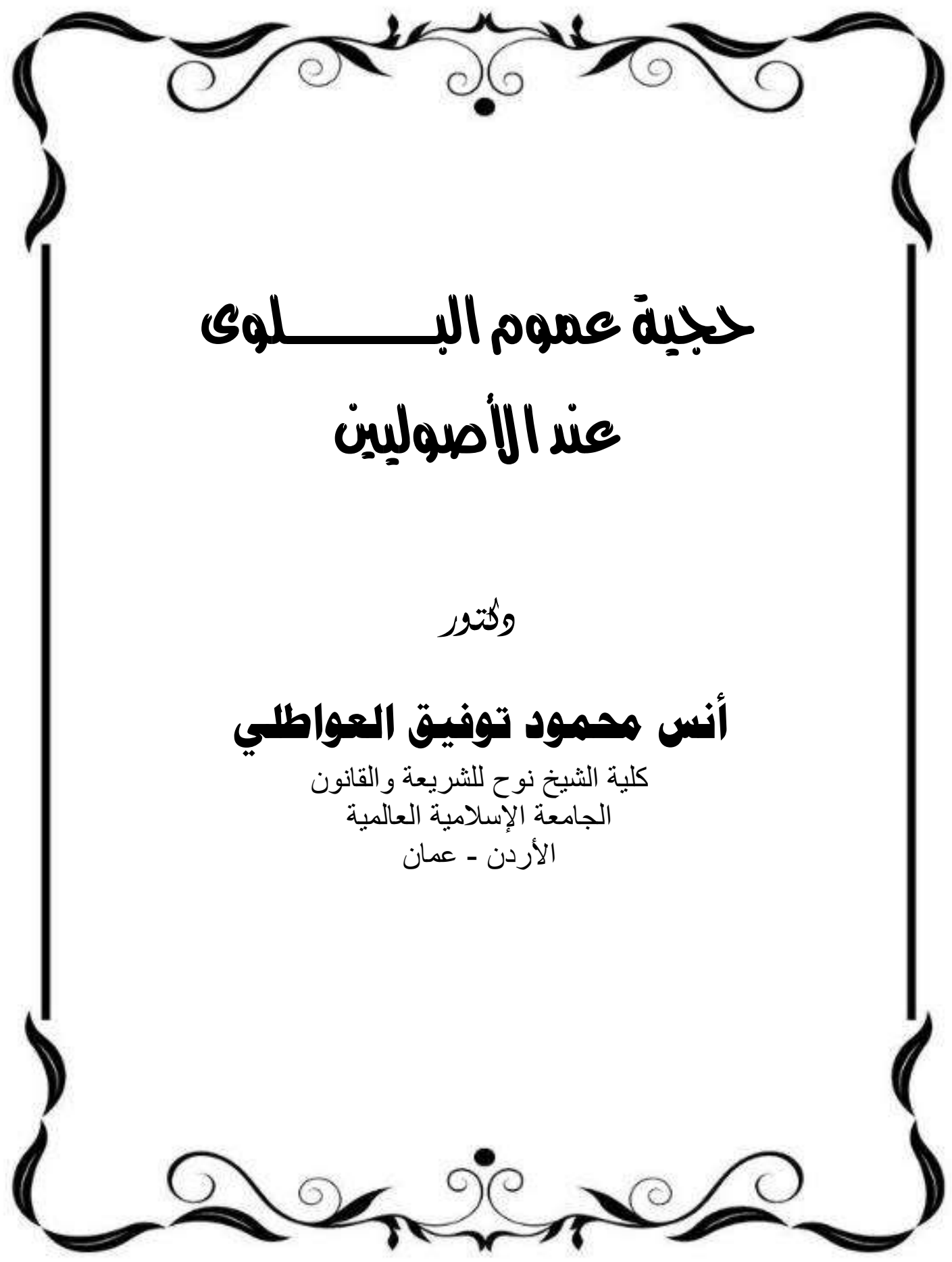




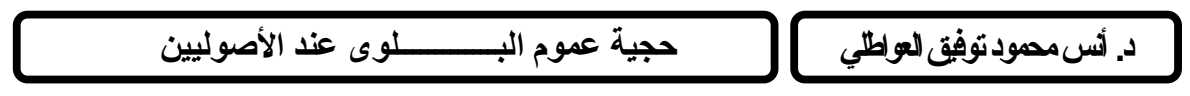

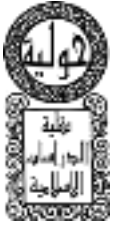


إصدار

حوليةكلية البراست الإسلاميةوالعرييةبنين القاهرة العلد (بr)
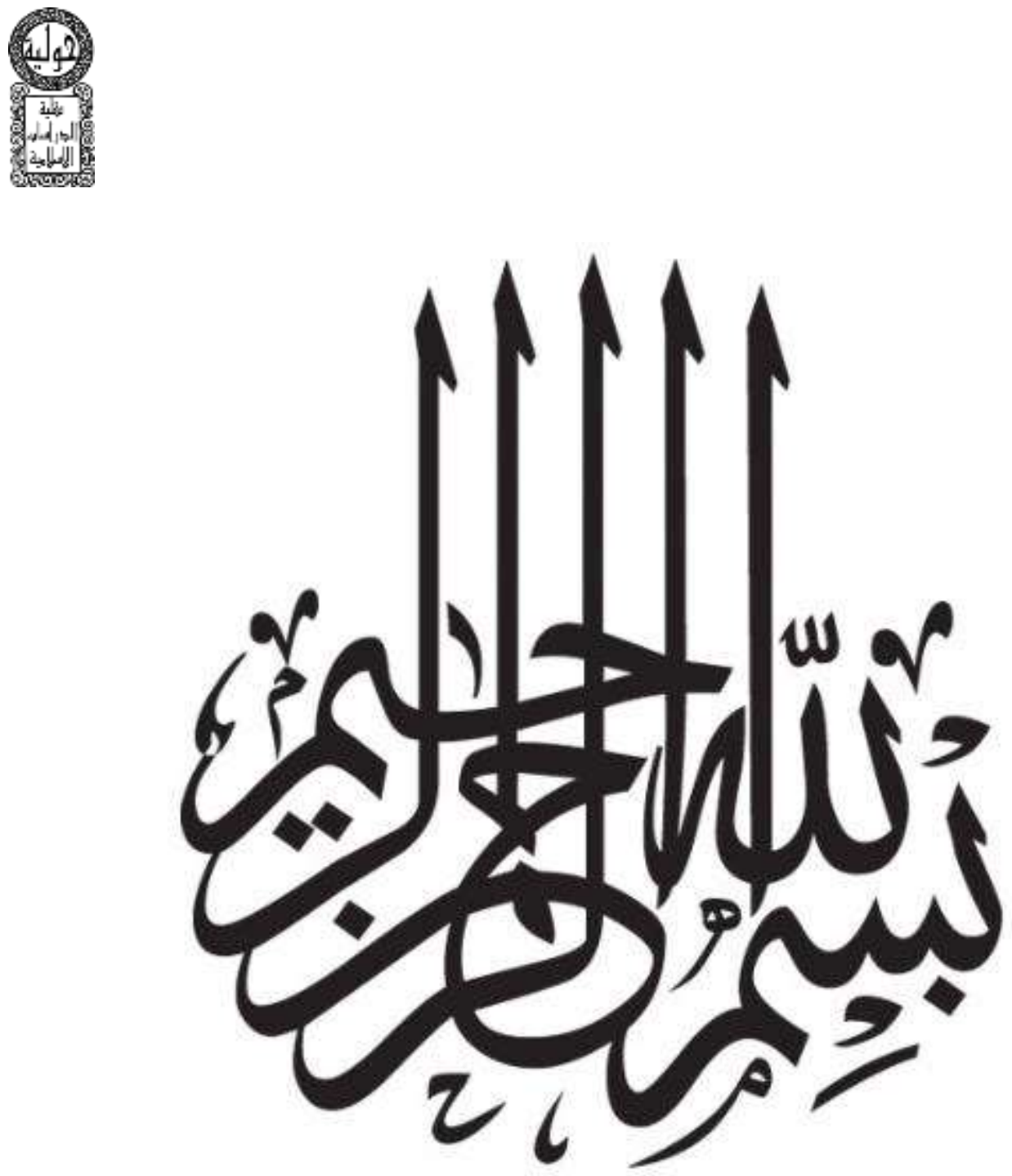


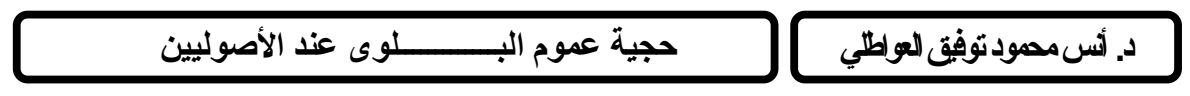

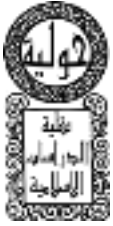




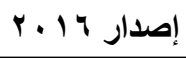$$
\text { حولية كلية اللراست الإسلاميةوالعبيةقبنين القاهرة العد (Tr) }
$$

\section{هلخص البهث}

نظر الأصوليون إلى حدوث الوقائع والمستجدات حتى تصبح من البلاء العام الذى قد يؤثز على النظر فى الأحكام الثرعية ، بين مانع ومجيز، ومشترط لبعض الثروط

وهذا البحث: فى حجيه عموم البلوى عند الأصوليين يغطى جانبا مهما من التعريف بعموم البلوى وأثرها على الحكم الثرعي وقد بنيته على أربعة فصول، وخاتمة، ومصادر . الأول: فى حقيقة عموم البلوى. والثانى: فى أدلة عموم البلوى وشروطه. والثالث: فى أسباب عموم البلوى. والرابع: فى صلة عموم البلوى بأصول الفقه. 


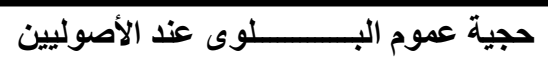

دـ أس محود توفيق العواطلي

Abstract

The Evidentiary Nature of Widespread Hardship According to Scholars of Legal Theory

Prepared By: Dr. Anas Mahmud Tawfiq al-'Awatili alRafi'i

Shaykh Nuh Ali Qudah Faculty of Shari'ah and Law

World Islamic Sciences and Education University

Some scholars of legal theory give evidentiary status to new situations that create widespread hardship, some don't, and some stipulate conditions. This study on the evidentiary status of widespread hardship according to the scholars of legal theory covers the import topics of the definition of "widespread hardship" and its effect on legal rulings. I have organized it into four sections, a conclusion, and a bibliography .

Section 1: The Definition of Widespread Need

Section $r$ : The Proofs of Widespread Need

Section r: The Causes of Widespread Need

Section \&: The Relation of Widespread Need to Legal Theory 


\section{الفصل الأول}

\section{في هقيقة عموم البلوى}

\section{المبـهذ 1الأول - عموم البلوى لغة:}

العموم لغة: مصدر من عَمَّ يَعُمّ عُموماً فهو عامٌ وهو في اللغة الثمول

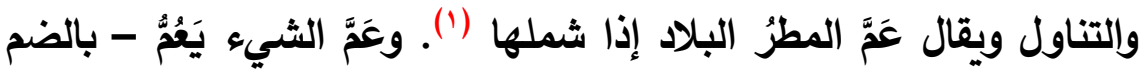
- عموماً أي شمل الجماعة منهم يقال عمَّهم بالعطية (ץ) إذا شملهم بهاء. ورجل مُعِمٌ يَعُمُّ الناس بخيره أي يجمعهم وكذلك مُلمٌٌِ يلمُّهم أي يجمعهم أيضاً ولا يكاد يوجد فعل فهو مفعل غيرهما ("). والبلوى في اللغة: اسم بمعنى الاختبار والامتحان يقال بَلوتُ الرجلَ بلواً

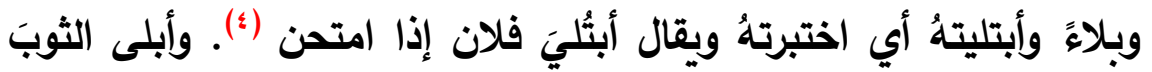

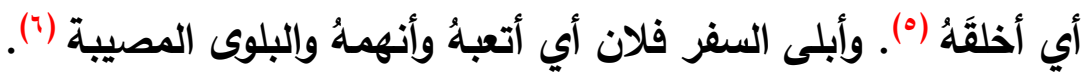
والبلاء الاختبار ويكون بالخير والثر قال تعالى: (ونبلوكم بالثر والخير

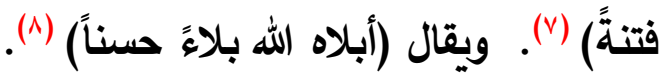

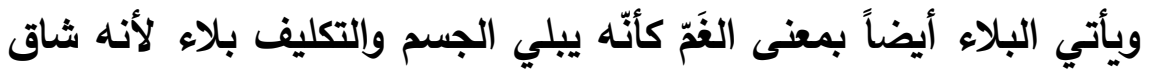
على الجسم والاسم البلوى والبليّة. والبَليّة هي المصيبة وفي الجاهلية

(1) الموسو عة الفقهية الكويتية(ج آس/ص ( ).

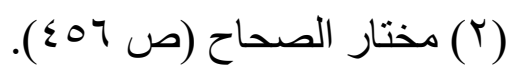

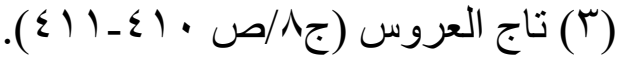

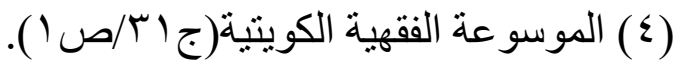
(0) أي صار خَلِقاً إذا أصبح قديماً أو غير صالح.

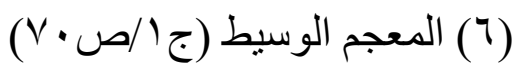

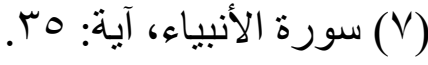

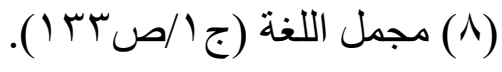


حجية عموم البـــــــــلـوى عند الأصوليين

د. أس محمود توفيق العولطي

البَليّة هي الناقة يموت ربها فتثد على قبره حتى تموت، كانوا يقولن أن

صاحبها يحضر عليها (1)

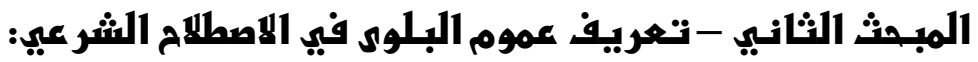

قبل البدء بتعريف عموم البلوى بالاصطلاح الشرعي لابد من أن نوضع

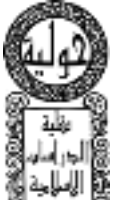

مسألتين:

المسألة الأولى: - أنى

إن عموم البلوى كتعريف اصطلاحي شرعي جامع مانع منضبط غير موجود في كتب المتقدمين من فقهاء وأصوليين فكل كتاب الفقهاء عند الوصول إلى جزئية تعم بها البلوى كسؤر الهرة واللجاج والمخلاة وسواكن البيوت (r) تكتفي بالإثارة إليه بأنه لا يمكن الاحتزار منه إلا بمشقة وأن البلوى به عامة وهكذا. أما كتب الأصولين فإنها قـ بحثت مسألة حجية خبر الواحد فيما تعم به البلوى مطولاً وبينوا كل شاردة وواردة في الباب ولكن عند البحث عن عموم البلوى كسبب من أسباب التيسير فإنّا نجد أنهم اكتفوا ببيان معناه ببعض الكلمات فقط وهذه القلة في البحث بالموضوع إن كانت مقبولة في كتب الفقه (). فهي غير مقبولة إطلاقًاً في كتب الأصول خصوصاً وأن الفقهاء قد بنوا أحكاماً كثيرة على عموم البلوى كما أن هنالك بعض المحاولات في زمانتا هذا لإباحة بعض المحرمات والتنازل عن بعض الثوابت الإسلامية بحجة أن الأمر مما عمت به

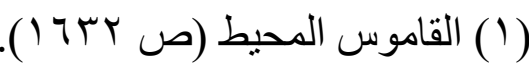

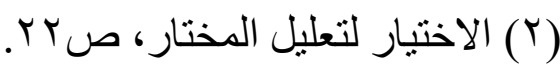
(r) وذلك أن كتب الفقه معنية بذكر الأحكام دون التفصيل بالدليل إلا في داري حال وجود خلاف أو إنكار من البعض. 
البلوى('). فلهذا لابد للأصوليين من وضع بيان شافي لعموم البلوى وشروط للاحتجاج بها حتى يكفينا الله شر هؤلاء المتربصين بدين الله وحتى يسهل للباحثين وطلاب العلم معرفة الموضوع معرفة تامة نافية للجهالة. المسألة الثانية: - (الثة إن تعريف عموم البلوى قد يختلف باختلاف المراد منه فكتب الأصول تبين عموم البلوى خلاف ما تبينه كتب الفقه ولا أقصد بالخلاف هنا النقيض بل الاختلاف في المعنى كل حسب ما يراه مناسباً لصنعته. ففي كتب الفقه غالباً ما نرى الفقهاء في المسائل الفرعية الفقهية يعبرون عن عموم البلوى بعسر الاحتراز أو عسر الانفكاك أو حرج التخلص منه والمشقة الزائدة (ץ). وغير ذلك أما الأصوليين فنجدهم يكتفون بثرحٍ بسيط له ولكنه يبين مرادهم منه مثلاً قول محمد إسماعيل الصنعاني في إجابة السائل: ومعنى عموم البلوى شمول التكليف لجميع المكلفين أو أكثرهم عملاً

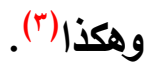
ومن هنا يتضح الفرق بين الفريقين في بيان المراد من عموم البلوى ونحن هنا في هذا البحث بصدد تعريف عموم البلوى تعريفاً أصولياً بحتاً كما لايخفى. تعريف عموم البلوى في اصطلاح الأصوليين:

(1) كمحاولة تبريد سفر المر أة والاكتتاب بأسهم بعض الثركات المحرمة.

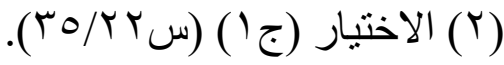

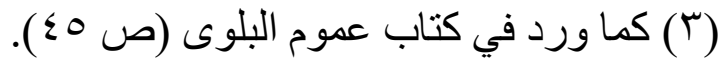




\section{حجية عموم البـــــــلـوى عند الأصوليين}

د. أنس محمودتوفيق العواطي

هو الحادثة التي تقع شاملة مع تعلق التكليف بها بحيث يعر احتراز المكلفين أو المكلف منها، يعسر استغناءهم عنها إلا بمشقة زائدة تقتضي لهي التيسير والتخفيف، أو يحتاج جميع المكلفين أو كثير منهم إلى معرفة حكمها مما يقتضي كثرة السؤال عنه أو اشتهاره بين المكلفين(') ومن التعريف يتبين لنا ما يأتي:

1- إن الأسباب الدافعة إلى عموم البلوى بالثيء تكون ناتجة عن

$$
\text { أمرين: }
$$

أ- عسر الاحتراز عن الثيء سواء كان هذا العسر ناتجاً عن قلة الثيء

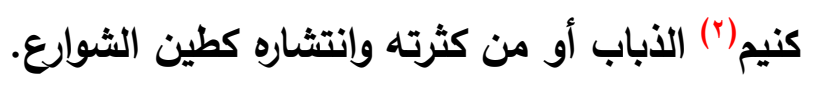

ب- أو قد يكون ناتجاً من عسر الاستفناء عنه وذلك كإبرام عقود البيع

$$
\text { عبر الهواتف دون اللقاء. }
$$

r- إن إن الصور التي تتحقق بها عموم البلوى تتمثل بما يأتي:

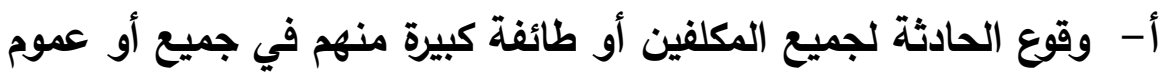

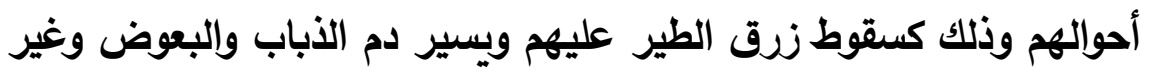
ذلك.

ب- وقوع الحادثة لجميع المكلفين أو طائفة كبيرة منهم في حال واحدة كطين الثوارع فإنه لا يكون إلا في حال المطر والمطر في جميع أيام

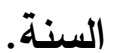
ت- وقوع الحادثة للمكلف الواحد في جميع أو عموم أحواله كالمريض والكبير في السنِّ أو من به سلس بول أو ريح.

$$
\begin{aligned}
& \text { (1) عموم البلوى (1) (7) بتصرف. } \\
& \text { (r) ما يخر من فضلاته }
\end{aligned}
$$


ما يخرج من فضلاته. إن تعريف عموم البلوى (هو الحادثة التي تقع شاملة مع تعلق التكليف بها بحيث يعسر احتراز المكلفين أو المكلف منها أو يعسر استغناء المكلفين أو المكلف عن العمل بها إلا بمشقة زائدة تقتضي التيسير والتخفيف). إلى هنا ينتهي حقيقةالتعريف ولكني ذكرت الباقي حرصاً مني على إدخال خبر الواحد من السنة النبوية فيما تقع به البلوى في مجال التعريف والبحث.

r- - أن العلماء المتقدمين الكرام كما هو دأبهم دائماً يحسنون اختياراً للكلمات ونقلها من حقيقة الوضع في اللغة إلى المعاني الاصطلاحية في العلوم المختلفة فكما أن الله تعالى ورسوله الكريم قد راعيا هذه المسألة في مختلف التسميات الثرعية('). نجد أن العلماء الكرام لم يففلوا هذه الصلة والربط بين اللغة العربية والعلوم الثرعية وهذا الأمر قد بدا واضحاً هنا في تعريف عموم البلوى فإناّ نجد أن العموم في اللغة الشمول وهذا أو ما بُدأ به في التعريف الاصطلاحي والبلوى هي المصيبة والغمّ وهذا المعنى مقصود أيضاً في التعريف الاصطلاحي لأن عمق البلوى في الاصطلاح ما هو إلا مصيبة ومشقة تصيب المكلفين أو المكلف على وجه يقتضي التخفيف والتيسير وهذا أمر عام موجود في كل الأسماء المنقولة إلى الاصطلاح الفقهي أو اصطلاحات العلماء في مختلف العلوم الثرعية وقد أحبيت أن أُنبه عليه هنا عرفاناً بجميلهم علينا في هذا المجال و أيضاً لضعف النظر في مثل هذه الأمور في أيامنا هذه.

(1) كالصلاة لغة الدعاء و اصطلاحاً هي العبادة المعروفة وذلك لعلاقة بينها مشتركة من حيث الدعاء. 


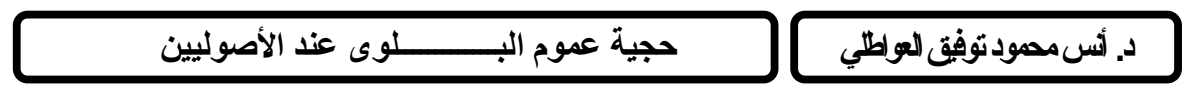

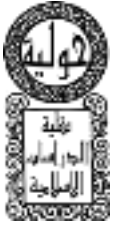


إصدار 17 ب ب

إصدار الفمل الثاني

\section{أدلة عموم البلدى وشروطه}

المبــث الأول - الأدالة الواردة على اعتبار عموم البلوى:

في البداية أود أن أقول أني لم أجد أحد قد بين الأدلة الواردة في عموم البلوى واعتباره حجه للأك عمدت إلى استقراء النصوص القرآنية والأحاديث الشريفة والبحث فيها كما حاولت أن أجد له أدلة من أقوال

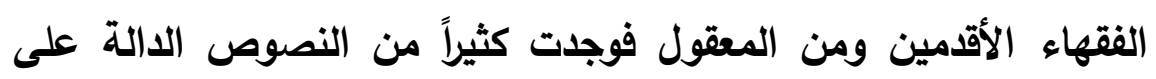
اعتبار عموم البلوى سبباً للتيسير والتخفيف حتى أن آيات القرآن الكريم والأحاديث الثريفة لا تكاد تخلو في مجملها من بيان أمر وهو أن الله تعالى يريد اليسر بالعباد ورفع المشاق عنهم وقد اخترت من هذه الأدلة ما يأتي: 1 - الأدلة من الآيات القرآنية الكريمة:

أ- قال تعالى ((هو اجتباكم وما جعل عليكم في الدين من حرج))('). وجه الاستدلال: إن الآية نص واضح صريح أن الله تعالى \}ما جعل في هذا الدين من ضيق ولا مثقة ولا كلفنا بما لا نطيق بل هي الحنفية

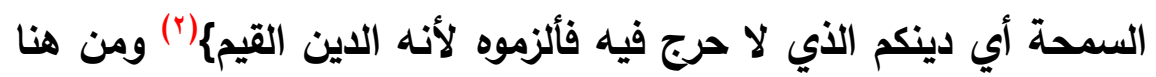

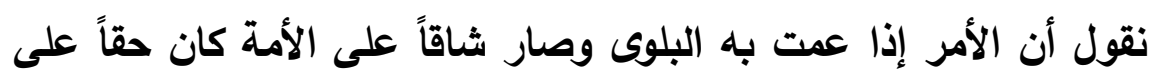
ربنا عز وجل رفعه بموجب هذه الآية الكريمة.

ب- قوله تعالى: ((يريد الله بكم اليسر ولا يريد بكم العسر)) (ऍ).

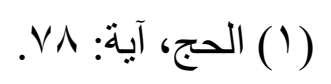

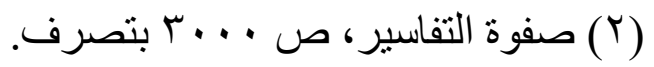

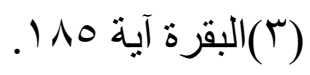

\section{1}




\section{حجية عموم البـــــــلـوى عند الأصوليين}

د. أنس محمودتوفيق العواطي

ت- قال تعالى: ((يريد الله أن يخفف عنكم وخلق الإنسان ضعيفا)) (')

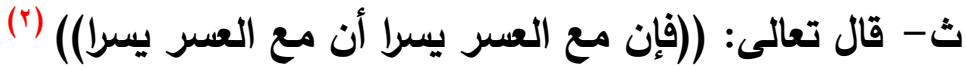

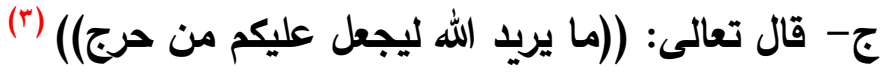
وجه الاستدلال بالآيات:

إن الآيات الكريمة جميعاً بينت أن الله تعالى لا يريد أن يثق علينا بشيء ولا يريد تعالى أن يحملنا ما لا نطيق ونصت الآية الثانية على ضعف الإنسان وعدم تحمله وأن هذا الضعف هو سبب التخفيف من الله تعالى. • مسألة: قد يقول قائل أن الآيات تدل على التخفيف والتيسير وليس على اعتبار عموم البلوى وأقول أن عموم البلوى من أهم أسباب التيسير ولو قلنا بعدم اعتباره لأصاب الناس حرج ومشقة كبيرة وهذه الآيات جميعاً جاءت نافية للحرج والمشقة وهذه نقطة ينبغي أن لا يغلفها أحد - والله

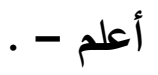

r - الأدلة من السنة النبوية:

أ- - قال رسول الله صلى الله عليه وسلم إإن الدين يسر ولن يثاد الدين أحد إلا غلبه|\{() . رواه البخاري. ب- - وقال من حديث طويل رواه الطبراني عن أبي أمامة رضي الله عنه جاء فيه \}بعثت بالحنفية السمحة)(॰).

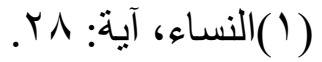

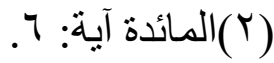

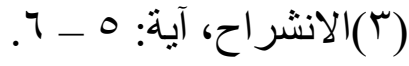

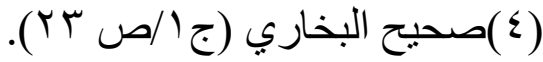

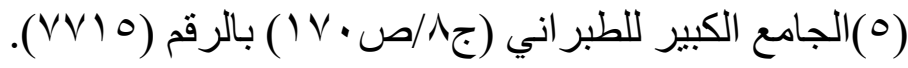


ت- وقال كإن الله شرع هذا الاين فجعله سمحاً سهلاً وإسعاً ولم يجعله ضيقائ (')

ث- وعن يحيى بن مالك عن عمرو بن يحيى عن أبيه أن رسول الله صلى

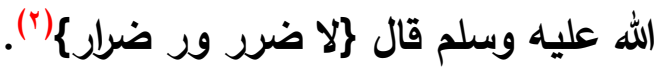
وجه الاستدلال :

إن النبي صلى الله عليه وسلم قد بين بالأحاديث السابقة أن الاين دين يسر وأنه سهل واسع لم يضيق الله به على الناس وإنه - صلى الله عليه وسلم - بعث بالحنفية السمحاء وكل هذه الاحاديث تتنافى مع الضرر الأي سيصيب الناس في الامور التي تعم بها البلوى بل أن الرسول الكريم - صلى الله عليه وسلم - قد أثبت أحكاماً تخفيفية في بعض الامور التي عمت بها البلوى وقد بين سبب ذلك كما في سؤر الهرة فقد روي عن عائشة رضي الله عنها انها أكلت من حيث أكلت الهرة فقالت قال رسول الله صلى الله عليه وبلم\} إنها ليست نجس إنما هي من الطوافين عليكمج وقد رأيت رسول الله صلى الله عليه وسلم يتوضأ بفضلهاب). رواه أبو من داوود وصححه الألباني وهذا الحديث أكبر دليل على اعتبار عموم البلوى لأن النبي صلى الله عليه وسلم اعتبره وذلك أن الهرة تصطاد وتأكل الميتة وتأكل من المزابل وغير ذلك فكان القياس حرمة سؤرها ولكن لما كانت البيوت آناك مليئة بها وقد يصيب الناس حرج كبير إذا لم يكن سؤر الهرة طاهراً وقد بين صلى الله عليه وسلم العلة بقوله فإنها من الطوافين

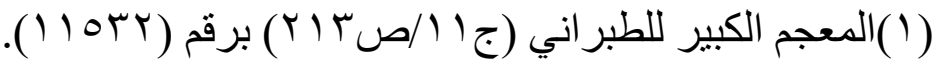

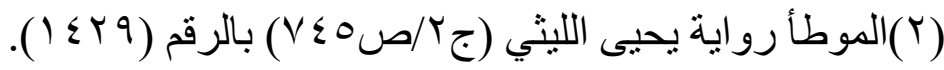

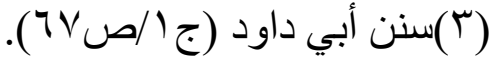




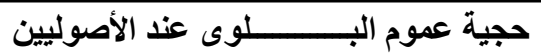

دـ أس محود توفيق العواطي

عليكم وهذا الطواف يقتضي عموم البلوى بها فكان سبباً لتخفيف الحكم والله اعلم.

r- الأدلة من اقوال الفقهاء ومن المعقول من اقوال الفقهاء: أ- كما لا يخفى على احد أن كتب الفقه قد استشهدت في مواضيع كثيرة بعوم البلوى لا سيما كتب الفقه الحنفي وذلك في فروع كثيرة كالحكم

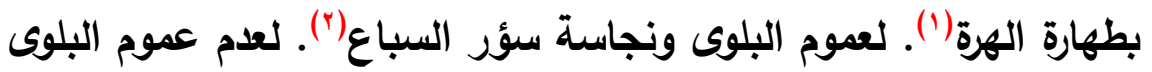
ومن أجله عفي عن رشاش النجاسات من طين الشوارع وعن الغبن في

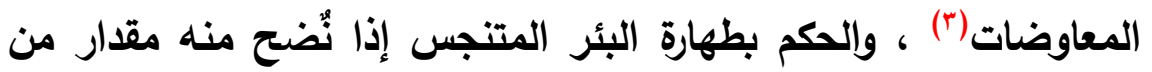

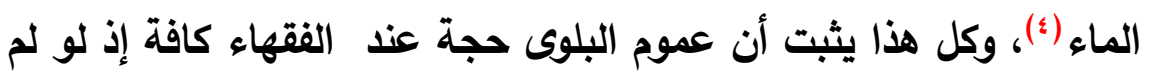
يكن كذلك لما أكثروا من الاستثهاد به في فروع الفقه.

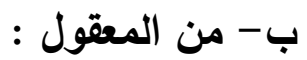
إن الله تعالى قد بعث النبي محمد صلى الله عليه وسلم وجعله خاتم النبيين ورسالته خاتمة الرسالات وأرسله إلى الناس كافة وق خص الله الاسلام بأمور كثيرة حتى يصلح لكل الناس في كافة الاماكن والأزمان وخصه ايضا بصفة اليسر والسهولة وعدم التكليف بما لا يطاقوهذا من رحمة الله تعالى بعباده المسلمين والتكليف بما تعم به البلوى إذا لم تكن في مقابلة مفسدة مساوية للمشقة أو أعظم منها ينافي السهولة واليسر والسماحة الموجودة في الاسلام. وقد بينا فيما سبق أن النبي صلى الله

$$
\begin{aligned}
& \text { (1) (1) (1) }
\end{aligned}
$$

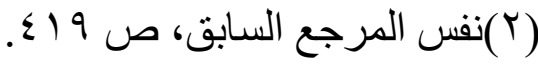

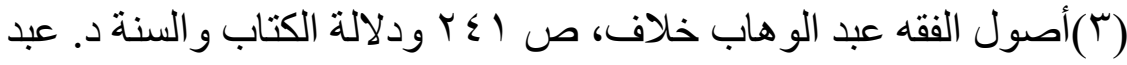

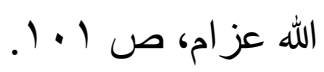

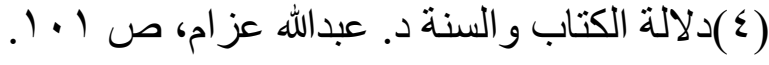


عليه وسلم بعث بالحنفية السمحاء، كما إنه لا مانع عقلا في التيسير في الامور التي تعم بها البلوى على عكس أن عدم اعتبار عموم البلوى يسبب حرجاً للمسلمين قد يحدو ببعضهم لاتخاذه حجة لترك شرع الله تعالى والابتعاد عن أحكامه فالعقل هنا يوجب مراعاة عموم البلوى والأخذ

المبـوث الثانبي - الثُروط الواجب توفرها للأفذ بعموم البلوى : بعد أن بينا الأدلة على أن عموم البلوى سبب معتبر من أسباب التخفيف والتسامع في الاحكام وأقمنا الحجة على ذلك من كتاب الله وسنة نبيه المصطفى - صلى الله عليه وسلم - ينبغي لنا أن لا نترك الباب مفتوحاً للأخذ بعموم البلوى في كل الاحوال والأمور حتى لا نفتح باباً للمغرضين الذين يتربصون بهذا الدين وحتى لا يصبح عموم البلوى سبباً للتملص من الاحكام التي شرعها الله تعالى فلهذا لابد لنا من ذكر ضوابط وشروط حتى لا يبقى عموم البلوى مطلقا يقول به كل من هب ودب ويتخذه حجة في الحق والباطل وحتى يسهل علينا معرفة متى يكون عموم البلوى حجة يجوز الأخذ به في التخفيف عن الناس ومن قراءتي للموضوع مطولا محاولاً استقراء الثروط الواجب توفرها في عموم البلوى تبين لي أنها كثيرة جدا تشترك في كثير منها مع أبواب وقواعد أصولية أخرى وقد حاولت حصرها بما يأتي : - يكون عموم البلوى حقيقاً لا متوهماً : وذلك بأن يكون لا يمكن الاحتراز عنه والاستغناء عنه حقيقة إلا بمشقة كبيرة كسؤز الهر وطين الشوارع ما إذا كان يمكن الاحتراز منه والاستغناء عنه وان كان بمشقة لكنها يسيره فلا يجوز القول بعوم البلوى فيه إذا أن التكاليف لا تخلو في 
مجملها من مشقة تتفاوت بالثدة ولكن هذا لا يعني أنها مما عمت به

r - أن يكون عموم البلوى متحققاً في عين الحادثة أما إذا كان غير متحقق فلا يجوز القول بعموم البلوى فيه كما لو كان أمام الشخص طريقان في أحدهما نجاسة والثاني سالم منه لا يجوز لله سلوك الطريق النجسة بحجة عموم البلوى في المسألة لأن الأمر يسهل الاحتراز منه. ب- أن يكون عموم البلوى متحققاً في جميع المتكلفين المخفف عنهم: وبيانه أنه لو كلن هناك عموم بلوى في أمر يتضرر منه جماعة كبيرة من الناس فإن الحكم يخفف عنهم دون البعض الآخر الأي لا يتضرر منه والمثال الآتي سيوضح المسألة بما لا يبقى أي خفاء فيها مثلا ذكر الفقهاء إن المطر يعتبر سببا للجمع بين الصلاتين لان الناس تتضرر منه أما من لا يتضرر منه كالإمام الساكن في المسجد والجار القريب من المسجد فلا يثبت له هذا الحكم(') على الأصح والله أعلم. ع - أن لا يكون المقصود من عموم البلوى الترخص: من الأحكام الثرعية وذلك كالمرأة التي تأخذ دواءً مباحاً لحصول الحيض بقصد الخلاص من أداء الصلاة أو الصوم أو غير ذلك(ب). ه- أن لا يكون الأخذ بعموم البلوى في مقابل نصوص شرعية تؤكد عدم جواز الأمر أو إن كان هذا الأمر من الثوابت الإسلامية فإن عموم البلوى هنا معتبر -

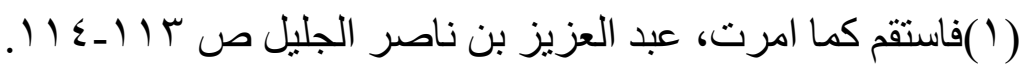

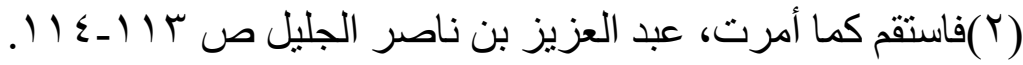


צ- أن لا يتم اثبات عموم البلوى بناء على واقع الأمة أي لا يقال أن الأمر مما عمت به البلوى فقط لأن كثير من الناس واقعون فيه ومثال الثرطين السابقين من يتذرع بعموم البلوى للقوم بعدم وجوب الحجاب للنساء وبجواز البنوك والثركات الربوية إذ أن النصوص قد جاءت مستوفية في الأمرين وأن واقع المسلمين المؤلم اليوم في الأمرين لا يكون سبباً في التخفيف عنهم لأنهم اعتدوا على أحكام الله ابتداءً فلا يقال أن الأمر عمت به البلوى بل هم من ابتلو انفسهم به. والحقيقة: أنَّ هذان الثرطين ياخلان ضمن الثرط الأول لأن عموم البلوى هنا متوهم وليس حقيقيا ولكني أردت أن انبه عليهما لأننا نسمع بين الفترة والأخرى مثل هذه الأقوال التي لم ينزل الله بها من سلطان. V- أن لا يؤدي عموم البلوى الى مفسدة مساويـة أو أعظم من المشقة الناتجة عن عدم التيسير وذلك كعموم البلوى في السفور فإنه لو اعتبر عموم البلوى فيه لأدى إلى مفسدة أكبر وهي انتثار الفساد والانحلال في المجتمع الاسلامي وكذلك زواج الصحابة من الحرائر الكتابيات فأن البلوى عمت به في زمانهم ولكنه لما بأ يؤدي إلى مفسدة أكبر وهي إفساد

\section{عقول أبناء المسلمين قيل بكراهيته(').} ^- أن يكون الترخيص في حال عموم البلوى مقيداً بتلك يزول بزوالها:

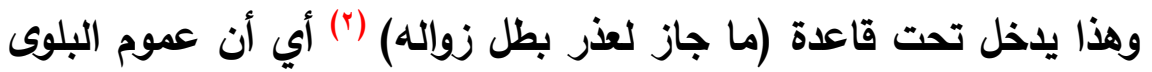
إذا انتفت انتفى الحكم المترتب عليها. 
لوى عند الأصوليين

حجية عموم الب

د. أس محمود توفيق العواطلي

9- أن لا يقبل قول أي شخص في اثبات عموم البلوى للأمور بل لابد

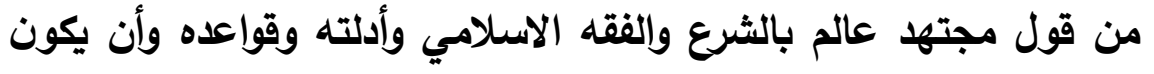
على علم بالأمر الذي عمت به البلوى. 


\section{إصدار 19 •}

حوليةكلية اللراست الإسلاميةوالعرييةبنين القاهرة العلد (Tr)

\section{النهل الثالث}

\section{أسباب عموم البلابوى}

إن أسباب عموم البلوى في الحقيقة ترجع كلها إلى سبب واحد رئيسي

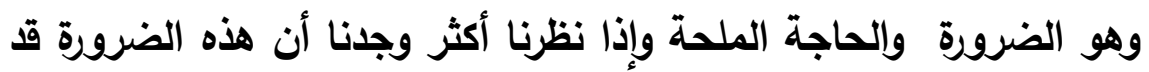
تكون ناتجة من عسر الاستغناء عن الامر أو عسر الاحترلز عنه فكل الأسباب هي فروع لهذين الأمرين ولكني قد رأيت فضيلة الاكتور مسلم الدوسري قد فصل القول في أسباب عموم البلوى ورتبها بطريقة علمية جميلة وسهلة في نفس الوقت فرأيت أن أتبع خطاه في هذه المسألة ولهذا فقد قسمت هذا الفصل إلى مبحثين.

\section{المبـ فن الأول - الأسبباب العامة لعموم البلوى :}

ونقصد بالاسباب العامة الأسباب التي يثترك جميع الناس أو معظمه فيها أو إمكانية وقوع جميع الناس في هذه الأسباب وإن لم تقع لبعضهم

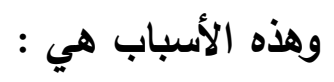

1 - صعوبة الثيء وعسر التخلص منه:

وذلك إذا تضمن الامر الذي ارتبط به فعل المكلف أمراً يصعب دفعه والتخلص منه('). وهذا من أهم الأسباب الدافعة على عموم البلوى الاهن بالشيء وكثيراً ما نوه إلى هذا الفقهاء في كتبهم بقولهم أن هذا مما لا يمكن الاحتراز عنه(ץ)أو عسر الاحتراز وغير ذلك. ومن أمثلة هذا السبب:

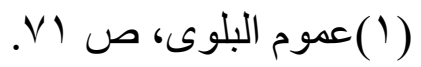

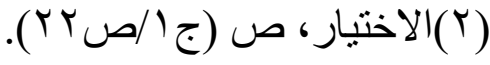


إنه عفي عن رشاش النجاسات المختلطة بطين الثوارع لصعوبة الاحتراز عنه(1). والماء التي تغير بالمكث والطين والطحلب المتصل به وما في مقره وممره فإنه يجوز الوضوء به لأنه لا يمكن فصل هذا الطين عنه (ץ). r - تكرار الثيء:

وهو تعدد وقوع الأمر للمكلفين أو المكلف في عموم احواله بما يوجب عسر الاحتراز عنه او صعوبة الاستغناء عنه ولهذا قال رسول الله صلى الهم الله عليه وسلم في الحديث الأي رواه البخاري عن ابي هريرة \}لولا أن أشق على أمتي لأمرتهم بالسوإك عند كل وضوء\{("). قد امتنع صلى الله عليه وسلم من إيجاب السواك لوجود المشقة المتمثلة بالتكرار.

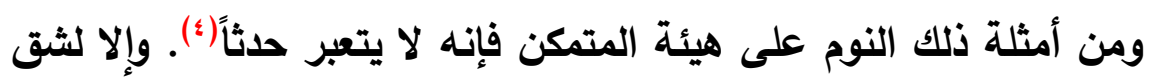
على الناس ذلك، كذلك عدم قضاء الصلاة بالنسبة للحائض وللمجنون بعد الإفاقة لأنهم يتكرر منهم الترك حتى صار الأداء يوجب المشقة. وقد نص الأمام الزركشي على هذا السبب في المنثور بقوله \} ولا يجب قضاء الصلاة على الحائض لتكررها بخلاف الصومج|(ه). r- شيوع الشيء وانتشاره: فإذا شاع الأمر أوجب عسر الاحتراز منه أو صعوبة الاستغناء عنه وشيوع الشيء من موجبات شمول جميع المكلفين أو أغلبهم بعموم

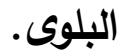

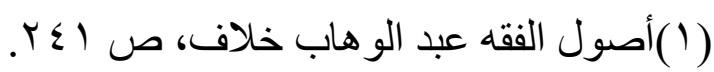

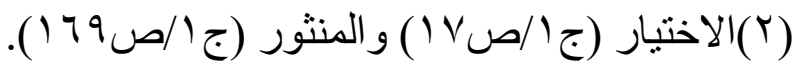

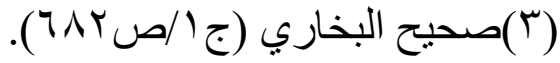

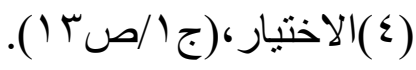

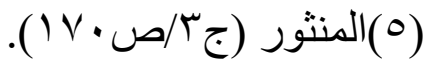




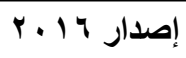

شيوع اختلاط الهرة بالناس ولهذا قيل بطهارتها ولو قيل بنجاستها لثق

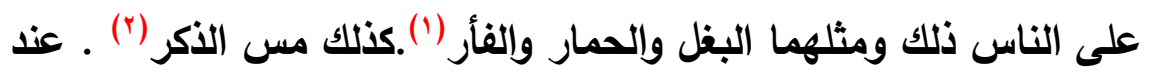
الحنفية فإنه مما تعم به البلوى حتى انهم ردوا به قبل الواحد(ّ).

$$
\text { ع - امتداد زمن الشيء : }
$$

معناه وقوع الفعل متصفاً بطول زمن الوقوع لعموم المكلفين أو للمتلف في عموم أحواله بحيث يلزم من التكليف به مشقه. ومن أمثلة ذلك:

قول الامام الزركثي في المنثور: \}تصلي المستحاضة ودائم الحدث مع النجاسة)(؛). وذلك لامتداد زمن النجاسة فلا يمكن الاحتراز عنها وقد بين العلة بعد ذلك بقوله \}حتى لا تضيع على الناس اورادهم\{(ه).

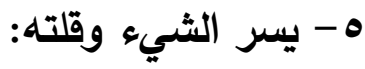
أي أن يكون الثيء قليلاً جداً مما يجعل الاحتراز منه أو الاستفناء عنه وفه

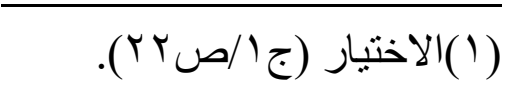

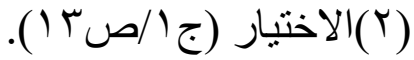

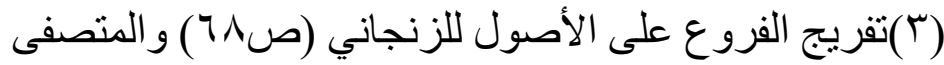

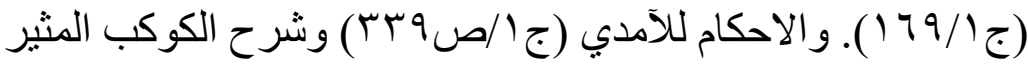

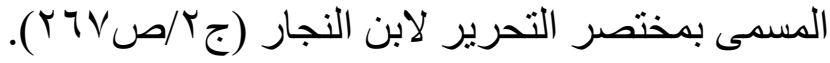

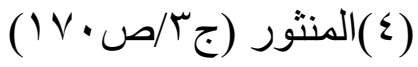

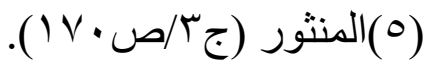


عسيراً وغالياً ما نجد الفقهاء يعبرون عن هذا السبب بالقلة أو بالنزارة واليسر (1). أمثلته:

العفو عن قليل دم البراغيث(ץ). إذا والعفو عفو ما لا نفس لله سائله كالذباب والبعوض والبق إذا مات في الماء فإنه لا ينجسه(ّ). وكذلك العفو

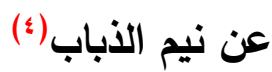

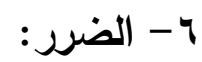

أي أن يكون الأمر المكلف به يسبب ضرراً للمكلفين في عموم أحوالهم أو في حال واحدة أو للمكلف عموم أحوالله فيصيبهم عسر من الاحتراز أو لأون عسر عن الاستغناء ودفع الضرر مطلوب شرعاً وله قواعد ثابتة في علم الأصول كالضرر يزال ولا ضرر ولا ضراروغيرها. أمثلة ذلك: القول بعد اشتراط نظر كل خاطب إلى المنكوحة(ه). فلو قيل بأشراطه لكان فيه ضرر لا يحتمله كثير من الناس لأخواتهم وبناتهم ومن ذلك تشريع الرجعة في الطلاق وذلك لأن الطلاق يقع بغتة في الخصام لذلك قد يصيب

(1)قد ذكر الامام الزركثي في المنثور ما نصه (يمكن للقاضي أن يجيب

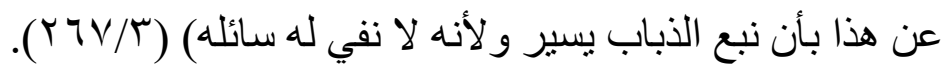

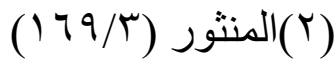

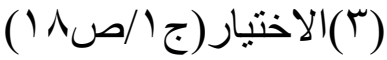

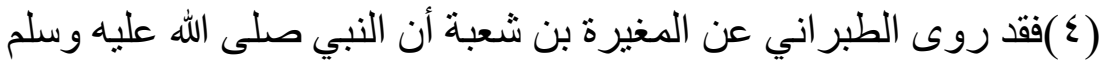

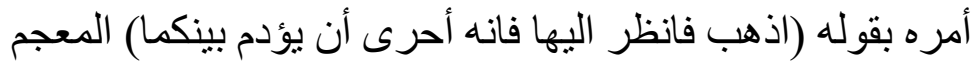

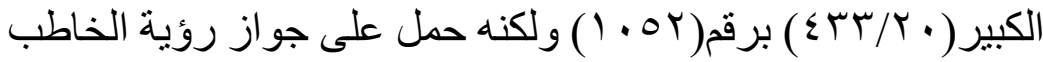
للمنكوحة دون جعله شرطا دفعا للضرر.

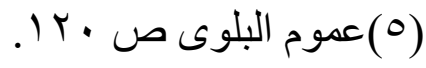


إصدار 14 ب ب

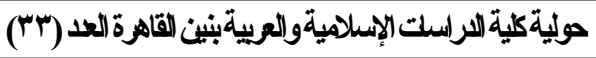

الزوج والزوجة ضرر عن عدم الرجعة(1). خاصة بعد هدوء الاعصاب وتذكر طيب كل واحد للأخر وفيه ضرر للأبناء وتهام لبيت الزوجية أيضاً،

فلهذا كله شرعت الرجعة في الطلاق.

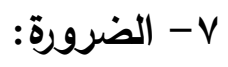

ومعناه أن يقع به المتكلف في حال تضطره إلى فعل أمر لا يجوز شرعا كأكل الميتة عند خوف الهلاك وغيره فالضرورة سبب مهم قد تعم به البلوى للمكلف في بعض الحالات أمثلة ذلك:

عموم البلوى بتعدد إقامة الجمعة في المدينة الواحدة وذلك للضرورة إذا كانت المدينة كبيرة كذلك كثف العورة للطبيب المعالج فيه أمر تعم به البلوى وهو ضرورة من ضرورات الناس ومن ذلك ما فعله سيدنا عمر بن الخطاب رضي الله عنه من رفع لحد السرقة في عام المجاعة وكانت البلوى قد عمت به والسبب لهذه البلوى هي الضرورة والله أعلى وأعلم. المبـمث الثاني - الأسباب الفاصة لعموم البلوى :

ونقصد بها الأسباب التي لا يشترك بها جميع المكلفين أو عموم في جميع الاحوال أو غالبها وذلك كالأسباب المتعلقة بالمكلف الواحد أو ما كان متعلقا بالفعل أو الحال ومن هنا يتبين أن أقسام الأسباب الخاصة ثلاثة: 1 - ما يرجع إلى المكلف: وذلك ككبر السن والمرض فإن هناك كثير من الاحكام تخفف عن المربض وكبير السن مراعاة لهما وتجنباً لتكيفهما بما لا يطيقان. أمثلة ذلك :

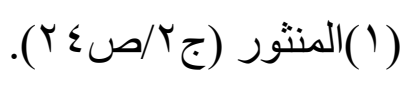


جواز ترك صلاة الجمعة والجماعة للمريض وكبير السن كذلك جواز ترك الصوم لهما وما ذلك إلا للتخفيف عنهما والمرض وكبر السن من الأمور التي تعم بها البلوى فكل مكلف معرض لكبر السن والمرض. r

وذلك كالحاجة إلى معاملة ما أو فعل من الأفعال بحيث يعسر على المكلفين الاستغناء عن هذا الفعل وقد قال الامام الزركشي في المنثور أن الحاجة العامة تنزل منزلة الضرورة الخاصة بحق آحاد الامة|\{('). ذلك إن الحاجة إذا عمت كانت كالضرورة. أمثلة ذلك:

اباحة الجعالة(ץ). وجواز الاجارة مع كونها عقد على منافع معدومة(ऍ) كذلك اباحة طعام الكفار للغانمين من المسلمين(؛)وجواز تمام عقود البيع عبر الهواتف دون اللقاء في المجالس واباحة عقد الاستصناع رغم أن القياس يأباه لانه بيع المعدوم(ه).

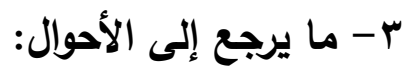

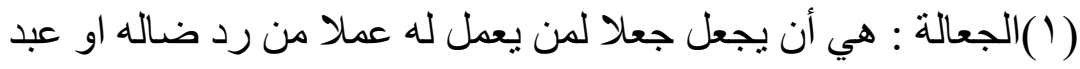

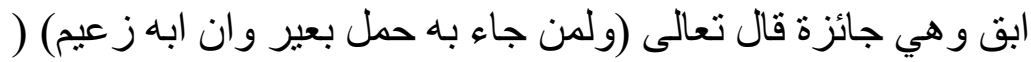

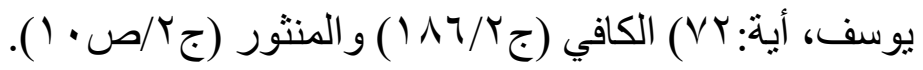
( Y $(Y / Y)(Y)$

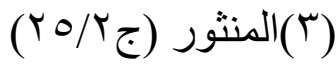

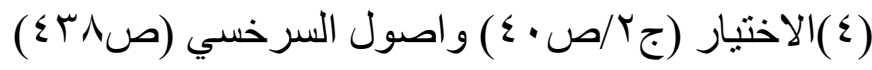

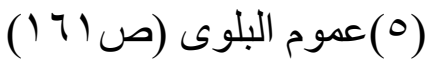




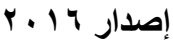

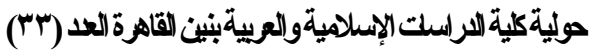

وذلك كالمطر والوحل والثلج (') فقد راعت الثريعة الاسلامية هذه الاحوال لما يمكن أن يتعرض لله المكلف في مثل هذه الاحوال من مشقات وصعاب التي تعتبر سببا للتخفيف عن الناس في مثل هذه الظروف. ولهذا نجد الامام الزركثي يقول بجواز ترلك الجماعة للأسباب العامة والخاصة(؟) والمطر والثلج من الأسباب الخاصة التي يجوز بها ترك الجماعة ومن الاحوال الاخرى التي لها نفس الحكم الضباب والحر الثديد ووقوع الكوارث والزلازل وغير ذلك.

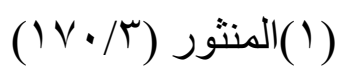

(Y)(المقصود أن السنة النبوية إذا وصلت الينا عن طريق الاحاد في أمر قد عمت به البلوى وذللك كحديث مس الذكر و الجهر بالبسملة ورؤية الهلال و غير ذلك. 


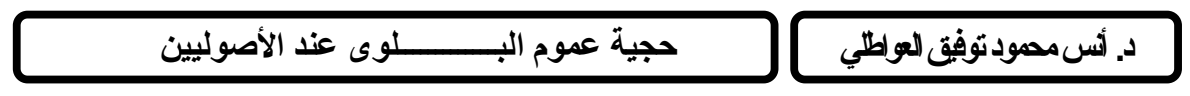

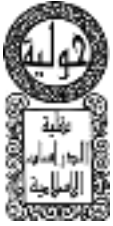




\section{الفصل الرابع}

\section{صلة عموم البلأوى بأصول الفقة}

إن لعموم البلوى صلة وثيقة بمباحث علم أصول الفقه بل هو جزء من مباحثه كما أن لله صلة أيضا بعلم الفقه، ونحن بصدد بيان صلة عموم البلوى وبيان كيف يؤثر عموم البلوى على حجية هذه الادلة والقواعد وكيف يؤثر على استنباط الاحكام الثرعية منها. المبـهن الأول - صلة عموم البلوى بـنبر الواهد: وهذا الموضوع قد أثبعه المتقدمون والمتأخرون من الاصوليين بحثاً حتى لم يكد يغفل عنه أحد وحاصل الامر أن خبر الآحاد فيما تعم به البلوى(') هل هو مقبول ام مردود فذهب جمهور الأصوليين والشافعي (r)وجميع اصحاب الحديث إلى قبوله والأخذ به إذا كان صحيح السند(ّ) وذهب الإمام أبو حنفية (؛) وابو الحسن الكرخي وجميع متأخري الحنفية إلى رده وعدم العمل به(ه) والحقيقة أن لكل واحد من الفريقين أدلة قوية على رأيه والخوض في هذه الادلة ومناقشتها ق يتطلب منا بحثا كاملا حتى نفي الأمر حقه ولكناً.

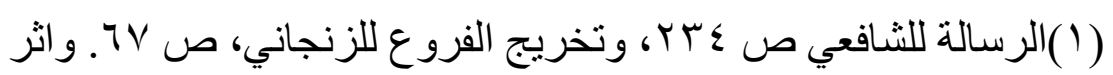

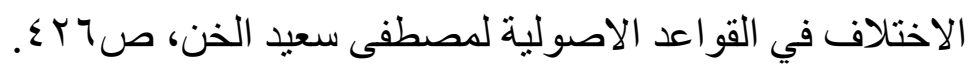

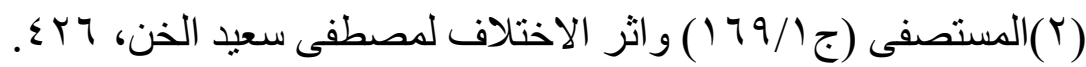

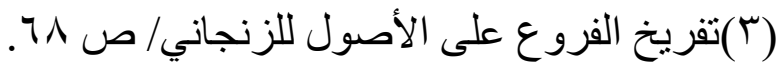

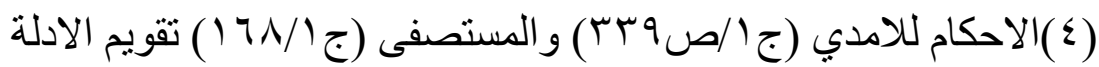

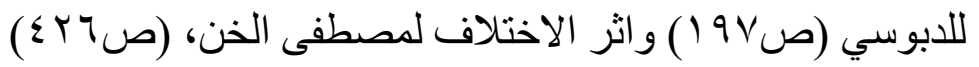


سنعمد الى عرض الأدلة ورأينا في الراجح من القولين وأثر هذا الاختلاف في الفروع الفقهية ونترك مناقشة الأدلة حتى لا يطول بنا المقام في هذا البحث وحتى لا نخرج عن المساق الأي حدناه لهذا البحث. أدلة القائلين بالعمل بخبر الواحد الذي عمت به البلوى: 1- ان النصوص قد وردت مطلقة في قبول خبر الواحد دون التفريق بين ما عمت به البلوى أو ما لم تعم به وذلك كقوله تعالى ((فلولا نفرمن كل فرقة منهم طائفة ليتفقهوا في الدين ولينذروا قومهم إذا رجعوا إليهم لعلهم يحذرون)) (").فان الله تعالى أوجب الإنذار على كل طائفة خرجت للتفقه في الدين ولو كانت أحاداً وهذا مطلق فيما تعم به البلوى وفيما

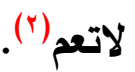
r - إجماع الصحابة : وهو أن الصحابة اتفقوا على العمل بخبر الواحد فيما تعم به البلوى وذلك بما روي عن ابن عمر قال كنا نخابر(") أربعين لا نرى بذلك بأساً حتى روى لنا رافع ابن خديج أن النبي صلى الله عليه وسلم \}نهى عن ذلك\{(؛) فانتهينا وكذلك رجوع الصحابة بعد اختلافهم

$$
\begin{aligned}
& \text { (1) سورة التوبة اية بr أ. }
\end{aligned}
$$

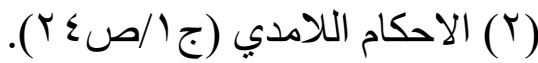

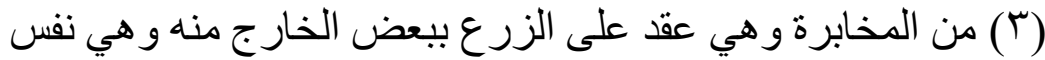
المز ارعة و المحاقلة.

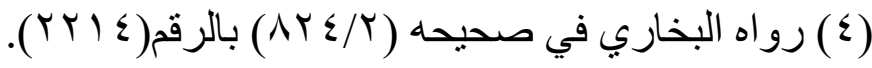


في وجوب الغسل من غير إنزال إلى خبر عائشة(') رضي الله عنها وكل هذه الأخبار آحاد وردت فيما تعم به البلوى(ץ) . r- المعقول: والاحتجاج به من وجهين الأول: أن الراوي عدل ثقة وهو جازم بالرواية فيما يمكن صدقه فلا يجوز تكذيبه(ऍ). والثاني أن انه يغلب على الظن فكان واجب الإتباع كالقياس (؛). أدلة القائلون بعدم العمل بخبر الواحد عمت به البلوى:

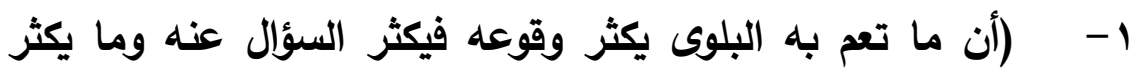
السؤال عنه يكثر الجواب عنه فيقع التحديث به كثيرا وينقل نقلا مستفيضاً ذائعا فإذا لم ينقل مثله دل ذلك على فساد أصله) (•) إذ لو كان أصله ثابتا لاثتهر حكم الحادثة لأخذهم الحكم عن النص("). r - - اختلاف الصحابة في كثير من الأمور التي جاءت بها أخبار من آحاد كاختلاف الصحابة في عدد الطلاق هل هو بالرجال أو بالنساء مع

(1) وذلك فيما رو اه ابن حيان في صحيحه عن عائشة رضي الله عنها أنها سئلت عن الرجل يجامع فلا ينزل قالت (فعلت أنا ورسول الله صلى على الله عليه

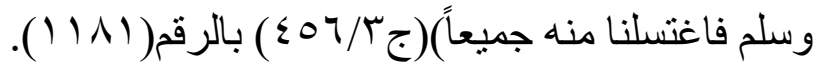

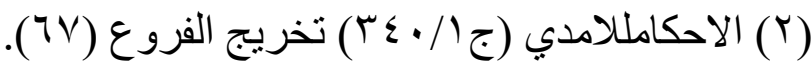

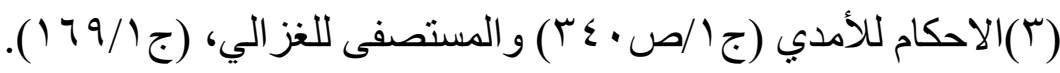

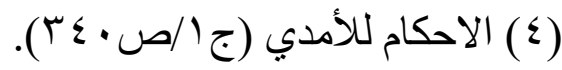

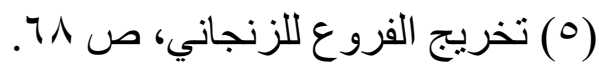

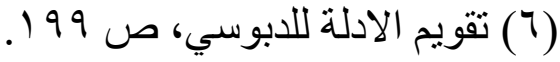




\section{حجية عموم البــــــــلوى عند الأصوليين}

دـ أس محود توفيق العواطي

وجود خبر مروي وهو (الطلاق بالرجال) ('). ولو كان خبر الآحاد حجة فيما تعم به البلوى لما اختلف به الصحابة.

r- - إن أكثر الاخبار التي عمل بها الجمهور يوجد هناك أخبار تعارض وهذا ما تبين لي من دراسة الفروع التي اختلف بها الطرفان مثلا الأخبار

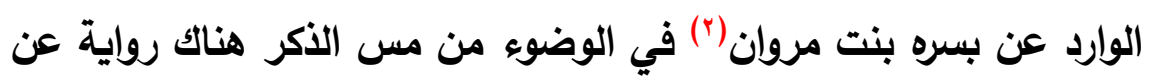
مروان بن طلق الحنفي تعارضها فقد ورد عن أبية قال سمعت رسول الله صلى الله عليه وسلم عن مس الأكر فقال: ( ليس فيه وضوء انما هو منك) (ّ). رواه (بن ماجه وصححه الالباني كذلك الاحادية الواردة في المخابرة وغير ذلك من الفروع. أما ما ورد في كتب الاصوليين من القول بأن الحنفية ناقضوا أصلهم هذا بقولهم بوجوب الغسل من التقاء الختانين(؛)وهو خبر احاد عمت به البلوى فهو غير صحيح وليس فيه دليل ذلك أن الحنفية يوجبون الغسل لأن التقاء الختانين سبب للانزال وهو متغيب عن البصر فقد يخفى على الثخص لقلته لهذا لم اذكر هذا الدليل ضمن أدلتهم لأنه ليس فيه حجة

( ( ) اخرجه الطبر اني في المعجم الكبير عن مسروق بن عبد الله قال

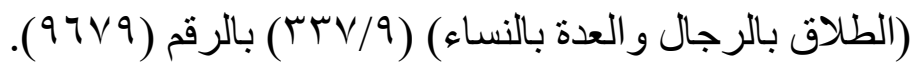

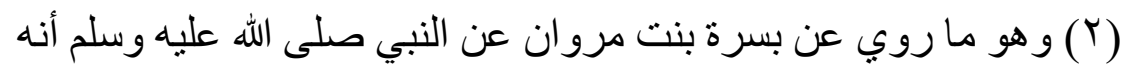
فال:( يتوضأ الرجل من مس الذكر ) رو رواه الطبر اني في المعجم الكبير

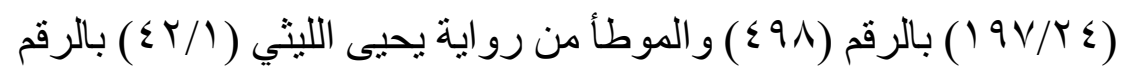

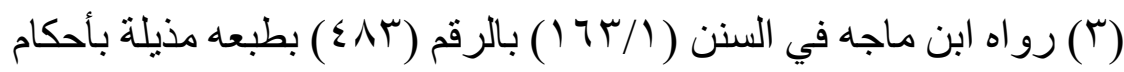
الالباني عليها. ( ()) وهو ايلاج من غير انزال راجع الهامش رقم (VY). 
إصدار

حوليةكلية اللراست الإسلاميةوالعربيةبنين القاهرة العلد (rاب)

أصلا وهذا مثال واحد من عدة أمور أوردوها كالتقاء الختانين وحكم الوتر

\section{وغيره.}

والذي أراه مما سبق من اقوال العلماء أن الجمهور ما قالوا بالعمل بالآحاد فيما تعم به البلوى إلا لخوفهم على السنة النبوية من أن يتجرأ عليها الجهال بحجة عموم البلوى وان راي الجمهور على وجاهته وقوة أدلته إلا لأن قول الحنفية أقوى وأسلم اما القوة فإن أدلة الحنفية العقلية لا غبار عليها هذا اضافة إلى انهم عضدوا قولهم هذا بفعل الصحابة بما لا يدع مجالا للشك في المسألة وأما كونه أسلم ذلك أن الدليل (إذا تطرق إليه الاحتمال سقط به الاستدلال) وهذا باتفاق الاصوليين وعموم البلوى بالثيء سبب في انتشار الخبر واثثتهاره فان لم يشتهر كان قاحا في نفس الاليل أو في تطرق الاحتمالات إليه يعني أن خبر الاحاد فيما عمت به البلوى أما أن يكون ضعيفا في ذاته أو ضعيف في احتمال وجود مخالفة له ولهذا لم يثتهر والله اعلم. الفروع الفقهية التي اختلف في حكمها الفريقين بناء على : 1 - ذهب جمهور العلماء ومنهم الثافعي وإحمد في احدى الروايتين عنه ومالك في المشهور عنه انه ينقض الوضوي غير أن الامام الشافعي خص ذلك بالمس بباطن الكف ومالك يثترط اللذة او العمد'('). واحتجوا بحديث بسرة بنت مروان (يتوضأ الرجل من مس الأكر) (؟).

(1) تفريج الفروع للزنجاني ص 1^7، واثر الاختلاف في القو اعد الاصولية

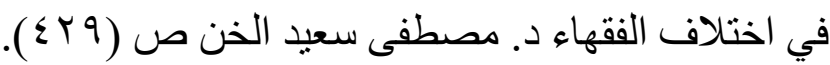

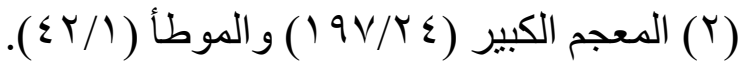


وذهب الحنفية أن مس الأكر غير ناقض للوضوء وقد احتجوا بحديث قيس بن طلق عن ابيه أن النبي صلى الله عليه وسلم سئل عن مس مس الأكر فقال (ليس فيه وضوء انما هو منك) ("). وقد ردوا حديث بسرة لان

الأمر مما تعم به البلوى عند الرجال(r). r - الجهر بالبسملة في الصلاة الجهرية: وذهب الثافعية إلى الجهر بالبسملة كما يجهر بالفاتحة واستدلوا بعده أحاديث قمت بتتبعها().فوجدت أن اصحها هو حديث نعيم المجمر قال صليت وراء أبي هريرة فقال (بسم الله الرحمن الرحيم ثن قرأ [ام الكتاب....) (؛).رواه ابن حبان في صحيحه وقال الثيخ شعيب الأرنؤوط (صحيح على شرط مسلم) لهذا فالبسملة واجبة عند الثافعية(•) وذهب الحنفية(†) إلى أن الجهر بالبسملة غير واجب واستدلوا بحديث قتادة عن أنس قال (كان رسول الله صلى الله عليه وسلم وابو بكر وعمر وعثمان يفتحون القراءة بالحمدلله رب العالمين) (v). قال أبو عيسى الترمذي

$$
\begin{aligned}
& \text { (1) سنن ابن ماجة (1/ (1 ( ) ). }
\end{aligned}
$$

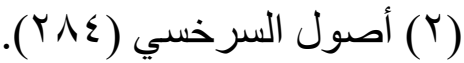

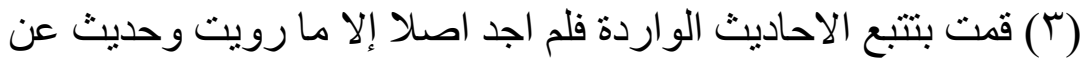

$$
\text { انس ذكره الثنافعي في كتاب الام. }
$$

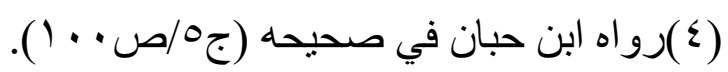

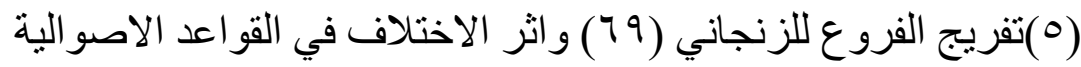

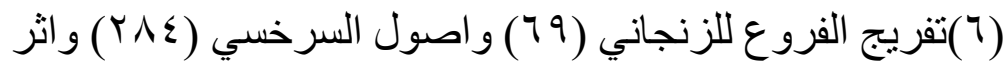

$$
\text { الاختلاف (•r؟). }
$$

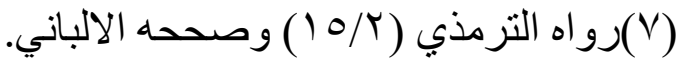


إصدار Y.14

حولية كلية اللراست الإسلاهيةوالعرييةبنين القاهرة (العد (rr)

حديث حسن صحيح وقال الالباني حديث صحيح ورد الحنفية الاحاديث

الواردة بالجهر لان الأمر مما عمت به البلوى وجاء بطريق الاحاد ('). r- ثبوت هلال رمضان:

فقد ذهب الثافعية إلى ثبوت هلال شهر رمضان بشهادة وإحد عادل واحتجوا بما روي عن ابن عمر قال(تراءى الناس الهلال فأخبرت رسول الله صلى الله عليه وسلم اني رأيته فصام وأمر الناس بالصيام) (ץ). ولم يفرقوا بين الصحو والغيم وغير ذلك(ّ). وذهب الحنفية إلى التفريق بين الصحو والغيم فإن كانت الدنيا غيم قبلوا شهادة الواحد وان كانت صحو لم يقبلوا إلا شهادة جمع من الناس يقع العلم بخبرهم ورد الحنفية الخبر السابق لكونه مما تعم به البلوى(؛). المبـثن الثناني - صلة عموم البلوى بـالإجما ع السكوتي : اولا: لابد لنا من بيان الاجماع والإجماع السكوتي قبل بيان علاقة عموم البلوى بالإجماع السكوتي. الإجماع: لغة العزم والاتفاق واصطلاحا : هو اتفاق مجتهدي الامة في عصر من العصور على امر ولو هذا الامر كان فعلا اتفاقا بعد النبي

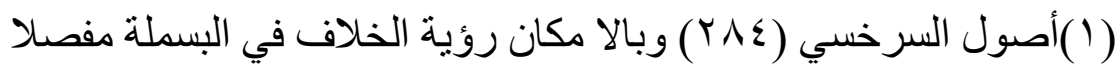

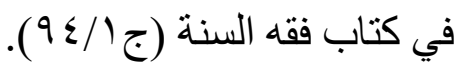

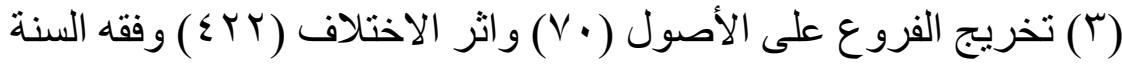

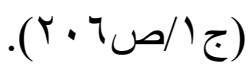

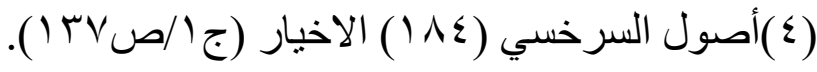


حجية عموم البـــــــلوى عند الأصوايليين

د. أس محمودتوفيق العوطلي

صلى الله عليه وسلم('). وهو حجة عند جميع الاصوليين ولم يخالف فيه إلا جماعة لا يعتد برأيهم (ץ).

الاجماع السكوتي: هو اتفاق بعض مجتهدي الامة على امر او فعل في عصر من العصور وسكوت الباقين مع علمهم. ولا يظهر منهم اعتراض وإنكار (ॅ). وهذا اختلف فيه الاصوليين بين مجيز وراد ومنهم من شرط له شروطا لم يجيزه بغيرها حتى حكا الامام الثوكاني في إرشاد الفحول عنهم أثنى عشر قولا وحاصل الامر أن الجمهور لم يعتبروه حجة والحنفية قالوا بحجيته (؛).

وعلاقة عموم البلوى بالاجماع السكوتي تأتي من باب أن الاجماع السكوتي إذا كان في أمر قد عمت به البلوى كان اولى بالوصول إلى كافة المجتهين الساكتين فهو سبب في زيادة القوة او الاجماع السكوتي وهذا الامر قد نوه إليه الامام الشوكاني بقوله ( إن كان الأمر مما يدوم ويتكرر وقوعه والخوض فيه فانه يكون السكوت فيه إجماع وبه قال إمام الحرمين الجويني) (•).

$$
\begin{aligned}
& \text { (1) مختصر التجريد (Y/Y/Y) وارشاد الفحول (YTY) و الاحكام للامدي (YT) }
\end{aligned}
$$

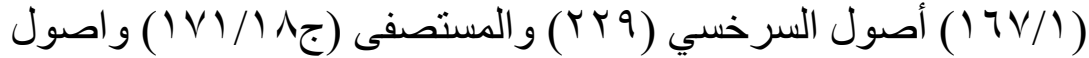

$$
\begin{aligned}
& \text { الفقه عبد الوهاب خلاف ( (0). }
\end{aligned}
$$

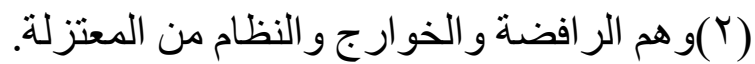

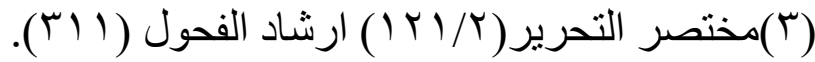

$$
\begin{aligned}
& \text { ( ( ) أصول الفقه عبد الوهاب خلاف (YV) (Y). }
\end{aligned}
$$

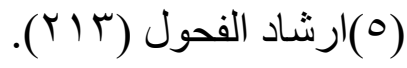


ومن هنا يمكننا القول بأن عموم البلوى سبب في تقوية الاحتجاج بالإجماع السكوتي لانه يوجب تناقل الخبر ووصوله إلى جميع الناس بما فيهم مجتهدي هذه الامة.

والغريب في الامر ما حكاه الثيخ عبد الوهاب خلاف من أن عدم الاحتجاج بالإجماع السكوتي هو مذهب الجمهور وان من احتج به هم الحنفية فقط لان الامام الثوكاني رحمه الله قد بين آراء العلماء كافة في هذه المسألة ولم يعد من الذين قالوا بأنه غير حجة إلا داود الظاهري والغزالي والرازي والامدي وهو قول الثافعي في الجديد وعند ذكر من قال بحجيته عد بعض الشافعية ورواية عن الامام الشافعي أضافه إلى كثيرين قالوا العمل به(') ولكن حسب شروطه. الفروع الفقهية للمسألة : - فقد ورد أن الناس كانوا يصلون صلاة التراويح عشرين ركعة في عهر سيدنا عمر بن الخطاب (ץ). رضي الله عنه، كذلك ورد هذا الامر عن الامام علي(ऍ). رضي الله عنه وهذه الحادثة لابد من انها وقعت على مرأى ومسمع كثير من الصحابة لانه أمر تعم به البلوى لأن الصحابة يصلون

(1) المسألة موجودة بالتفصيل مبحث الاجماع السكوتي في ارشاد الفحول

(Y) الموطأ من رواية يحيى الليثي عن يزيد بن رومان قال (كان الناس (ب) يقومون في زمان عمر بن الخطاب في رمضان بثلاث و عشرين ركعة)

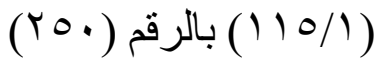

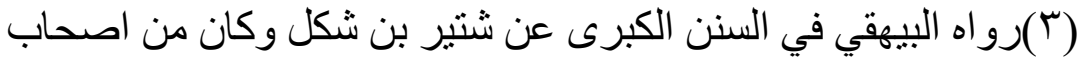

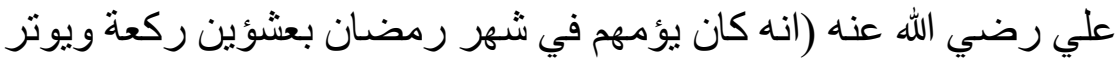

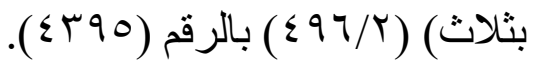

\section{5}


خلفهم فلابد من علمهم فلما صلى خلفهم الصحابة عشرين ركعة دل على إجماعهم على جواز التنفل بعشرين ركعة على الرغم من أن الرسول صلى الله علي وبلم قد صلاها ثماني ركعات. r

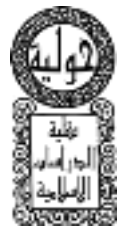
فقد ورد عن امير المؤمنين عمر بن الخطاب رضي الله عنه وعن علي بن أبي طالب رضي الله عنه ، أنهم كانوا يضمنون الاجير المشترك حتى أن الامام علي كان يقول (لا يصلح الناس إلا ذلك) (؟). وهذا الأمر مما يحتمل بلوغه إلى جميع الصحابة او عدم بلوغه ولكنه لما كان أمرا تعم به البلوى فان احتمال بلوغه أقوى فكان اجماعا سكوتيا في هذه المسألة والله أعلم. الهبـث الثالث - صلة عموم البلوه بالقباسر: القياس : لغة التقدير واصطلاحا: هو الحاق واقعه لا نص على حكمها بواقعه ورد نص بحكمها في الحكم الأي ورد به النص لتساوي الواقعتين في علة هذا الحكم)(ّ). فالقياس هو عبارة عن اثبات حكم النظير لنظيره إذا تساويا في العلة والوصف وهذا الوصف قد يكون امرا عمت به البلوى ومن هنا تأتي علاقة عموم البلوى بالقياس فإن عموم البلوى يصلح أن يكون علة بالقياس

(1) الاجير المشترك هو الذي يعمل لعامة الناس ويقع العقد معه على فعل لا عليه كالخياط العام وباقي أصحاب الصنائع. (r)(السنن الكبرى/ورد عن الثافعي قوله (قد روي من وجه ى يثبت أهل الحديث مثله أن علي بن ابي طالب ضدن الغسال و الصباغ وقال ونال لا يصلح

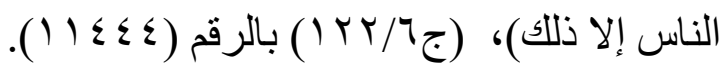

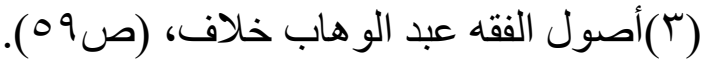


وسنوضح ذلك بالأمثلة التي سنسوقها بعد قليل ولكن لابد من توضيح نقطة مهمة وهي أن علاقة عموم البلوى بالقياس تختلف عن علاقته بخبر الواحد وبالإجماع السكوتي لأنه فيهما يكون سببا لقوة الاحتجاج بهما او ضعفه.

اما هنا فانه سبب لتعدية الحكم الخاص بالواقعة التي فيها نص إلى اختها التي ليس فيها نص وهذه نقطة يجب الانتباه اليها. امثلته: قياس ملامسة غير الهرة من البغال والحمير ولمس الفأرة وغير ذلك من الامور التي عمت بها البلوى لكونها من الطوافين علينا ولعدم إمكان الاحتراز عنها فإنها تقاس على الهرة في عدم نجاستها فالنص قد ورد في الههة فقط والبقية قد قيست عليها كذلك قياس سلس البول على الاستحاضة في جواز الجمع بين الصلاتين بوضوء واحد لاثتراكهما في العلة وقياس الاغماء على الجنون في عدم وجوب قضاء الصلاة الفائتة أثناء الاغماء لأنه أمر تعم به البلوى للمغمى عليه لأنه قـ يغمى عليه أياما عدة مما يشتق عليه القضاء (1). المبـهث الرابـو - صلة عموم البلوك بـالاستمسيان: الاستحسان لغة وجود الثىء حسنا واصطلاحا نوعان: الأول العمل بالاجتهاد غالب الرأي فيما أوكله الثرع إلى آرائنا مثل المتعة المذكورة في قوله تعالى ((متاعا بالمعروف حقا على المحسنين)) (ץ). وأوجب ذلك بحسب الاعسار واليسار في الزوج وكذلك قوله تعالى (( وعلى

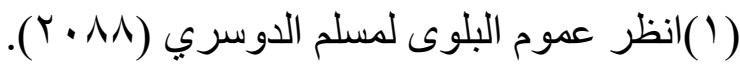

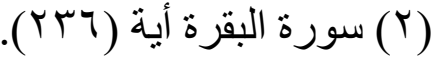




\section{حجية عموم البـــــــــــوى عند الأصوليين}

دـ. أس محمودتوفيق العواطي

المولا لله رزقهن وكسوتهن بالمعروف)) ('). وهذا قد اتفق الفقهاء على

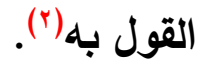

الثاني : هو العدول عن قياس إلى قياس اقوى منه،.("أو هو ترك القياس الجلي والأخذ بالقياس الخفي لاليل ينقدح في ذهن المجتهد.

وهذا قد اختلف فيه فأنكره الشافعية(؛)وورد عن الامام الشافعي انه قال (من استحسن فقد شرع) وأجازه الحنفية(•) والخلاف في الاستحسان حقيقة هو خلاف في معناه فالشافعية لا يقبلون القول بالرأي في الاحكام الشرعية وهذا أمر يأباه السادة الاحناف أيضا ولكن إذا كان العمل بمقتضى دليل في الحادثة وان كان يخالف قياسا جليا فهو عمل بالاليل وليس قول بالأهواء دون اعتماد ادلة فالاستحسان هو قياس بلاليل ولكنه يخالف قياسا آخر وهو راجح عليه عند المجته وللتفريق بين القياسين قام الحنفية بتسمية القياس الراجح استحسانا(")، هذا هو خلاصة الخلاف

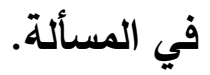
أن القياس وعلاقة عموم البلوى بالاستحسان يأتي من باب كون دليل الاستحسان أمرا قد عمت به البلوى فعموم البلوى بالمسالة قد توجب ترك القياس إلى الاستحسان وقد بين الامام السرخسي هذه المسالة في أصوله اذ قال: [أن ترك القياس يكون بالنص تارة وبالإجماع اخرى وبالضرورة

$$
\begin{aligned}
& \text { (1) سورة البقرة أية (TMT). } \\
& \text { (Y) أصول السرخسي (Tr) (T). }
\end{aligned}
$$

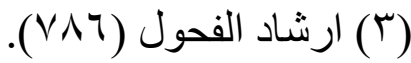

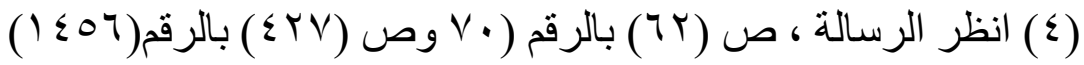

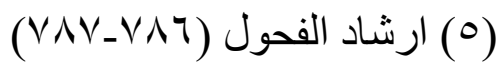

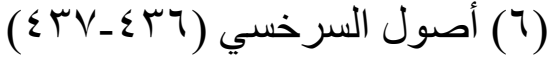


أخرى فترك القياس بالنص كأكل الصائم الناسي والرخصة في السلم رغم أن القياسي يأباه وأما ترك القياس بالإجماع فكعقد الاستصناع فان القياس يأباه ولكن فيه اجماع وأما ترك القياس للضرورة فنحو الحكم بطهارة الآبار والحياض بعدما تنجست إذا نزح منها مقدار من الماء فان القياس يقضي بنجاستها لان ما يرد عليه النجاسة يتجس بملاقاتها ولكنا تركناه

للضرورة المحوجة إلى ذلك لعامة الناس والصرج مدفوع بالنص] ('). فانا نجد الإمام هنا قد نص على أن عموم البلوى يكون سببا للاستحسان ولترك القياس والضرورة هنا هي عموم البلوى بالمسألة وقد بينه هو بقوله ((الضرورة المحوجة إلى ذلك لعامة الناس) والضرورة سبب من

أسباب عموم البلوى كما سبق وقدمنا في الفصل السابق(؟). إذا فعلاقة عموم البلوى بالاستحسان هي علاقة السببية لان عموم البلوى قد تكون سببا للاستحسان كما أن النص والإجماع يكون سببا لله والله اعلم. أمثلته من الفروع الفقهية: 1 - الحكم بطهارة الآبار والحياض بعد تنجسها وذلك أن القياس يقتضي الحكم بنجاستها وذلك لانها تنجس بمجرد ملاقاة النجاسة كما هو معروف فلا يمكن الحكم بطهارتها ولكن لما كانت البلوى بها عامة والناس بحاجة لها قيل بطهارتها استحسانا إذا نزح منها مقدار معلوم من الماء(").

(1) منقول من أصول السرخسي (ص^^ץ؟) بتصرف قليل.

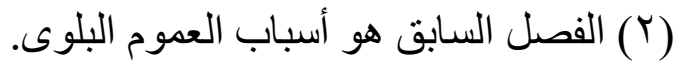

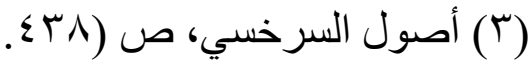


r - طهارة الثوب النجس إذا غسل في الاجانات (( الطشت )) فانا القياس يأباه لأن الثوب النجس إذا وضع في الماء فانه ينجسه ولا يمكن للماء النجس أن يطهر شيئا ولكنا قلنا بطهارته استحسانا حتى لا يصيب الناس حرج لان حاجتهم إليه شديدة(')

ع - سؤز سباع الطير والقياس فيه النجاسة اعتبارا بسؤز سباع الوحش بعلة حرمة التناول وفي الاستحسان لا يكون نجسا لان السباع

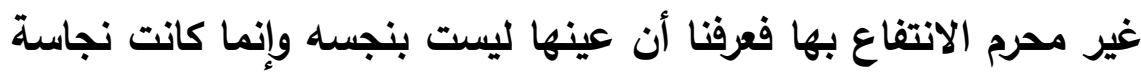
سؤر سباع الوحش باعتبار حرمه الاكل لأنها تشرب بلسانها وهو رطب من لعابها ولعابها يتولد من لحمها وهذا لا يوجد في سباع الطير لأنها تأخذ الماء بمنقارها ثم تبتلعه ومنقارها عظم جاف والعظم لا يكون نجسا من الميت فكيف يكون نجسا من الحي ثم تأيد هذه العلة المنصوص عليها في الهرة فان معنى البلوى يتحقق في سؤز سباع الطير لأنها تنقض من الهواء ولا يمكن صون الأواني عنها خصوصاً في

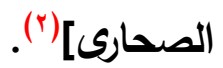
ه - - وحرصت على ذكر هذا المثال منقولا كما وجلته في كتاب أصول السرخسي لأبين أمرين أولا: الأول: أن المتقدمين قد عرفوا عموم البلوى باسمه كما ورد بقوله (فان معنى البلوى يتحقق..) كما عرفوا البلوى بأسماء أخرى كالضرورة والحرج والمشقة وعسر الاحتراز وصعوبة الاستغناء وغيره مما تغص به كتب الفقه والأصول على الرغم من أنهم لم يفصلوا القول فيه بل ولم يفردوه بباب أو فصل في كتب الأصول رغم

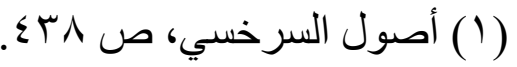

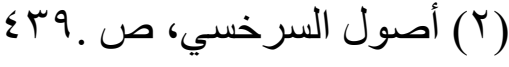


كونه مادة دسمة غنية تستحق أن تدرس لاسيما أنها سبب في اختلاف الفقهاء في المسائل الفقهية كما هي سبب في اختلاف الأصوليين في المسائل الأصولية ولكني أظنه لم يدرسوها لأنهم كانوا متفقين على كون عموم البلوى سبب من أسباب التخفيف في الأحكام إذا جاءت مستوفية لشروطها.

צ- الأمر الثاني : الأي أحببت أن أبينه هو الفرق الثاسع بين طريقتنا نحن في سوق الأمثلة وطريقة المتقدمين فرغم تطور العلم وسهولة اكتسابه في أيامنا هذه إلا أنهم فاقونا في حسن إظهار الفكرة. وفي اختصار الكلمات وجودتها وطريقة إثبات الأمور والاستدلال بالعقل عليها وهذا من فضل الله تعالى عليهم لصدقهم مع الله - سبحانه وتعالى - فسأل الله تعالى أن يرزقنا غيضا مما أفاض به عليهم انه على ما يثاء قدير وبالإجابة جدير وهو نعم المولى ونعم النصير. المبـهث الفامسر - صلة عموم البلوى بسيد الذرائر وفتهما: الأريعة : لغة الوسيلة وسد الرائع اصطلاحا: هي المسألة التي ظاهرها الإباحة ويتوصل بها إلى فعل المحظور وذهب مالك إلى منع الأرائع وقال أبو حنفية والثافعي لا يجوز منها('). وتبرز الصلة بين عموم البلوى وسد الأرائع من خلال النظر فيما يترتب على التيسير في الأمور التي تعم البلوى، فإذا ترتب عليه مفسدة مساوية أو أعظم فان عموم البلوى لا يعتبر هنا لأنه في هذه الحالة يكون وسيلة يتوصل بها إلى فعل المحظور فلابل من سدها وهذا من باب سد الأرائع أما إذا كان في اعتبار عموم البلوى تحقيق مصلحة بحتة او مصلحة في مقابل مفسدة أقل عدم

(1) إرشاد الفحول، ص ع • (1). 
حجية عموم البـــــــــلـوى عند الأصوليين

د. أنس محمود توفيق العواطي

التيسير على الناس فان عموم البلوى يعتبر هنا تحصيلا لهذه المصلحة وهذا يكون من باب فتح الذرائع|(')من هنا تبين لنا العلاقة بين عموم البلوى وبين سد الذرائع فكما بينا سابقا في معرض الحديث عن شروط اعتبار عموم البلوى أن عموم البلوى لا يعتبر إذا كان في مقابلة تحقيق مفسدة مساوية او اكبر منه وهذا لاثك هو من باب سد الأرائع حتى لا تكون عموم البلوى سبباً للتطاول على شرع الله وأحكامه. أمثلته من الفروع: - 2 - - سد باب الاحتكار بوجه التجار رغم أنها أمر يتضررون منه يضمن لهم الربح الوفير ولكنه لما كان ذربعة للطمع والجشع وسبب في التضيق على الناس قيل بحرمته سداً للذربعة. r - نكاح الحرئر الكتابيات وهو أمر مباح ولكن لما عمت به البلوى في زمن الصحابة حتى خيف على صبيان المسلمين من الأمهات الكتابيات أن يقمن بالعبث بعقولهم قيل بكراهته سداً للذربعة. ب- - دفع فدية للكفار في سبيل إطلاق أسرى المسلمين فيه أضرار بالمسلمين لأنه أمر يقوي عدوهم ولكنه لما كان فيه مصلحة أكبر وهي تقوية صفوف المسلمين بالأسرى وردهم إلى ديارهم سالمين قيل بجوازه وفتح الأربعة فيه. ع - دفع رشوة للحاكم الظالم لاتقاء شره رغم أن فيه فتح ذربعة الرشوة على أنهم قالوا بجوازه تحصيلاً لمنفعة اكبر وهي حفظ النفس من شر جور هذا الحاكم ففتحت الذربعة فيه تحصيلاً لهذه المنفعة والله اعلم واعز

(1) انظر : عموم البلوى لمسام و الدوسري، ص 0 اب؟ 


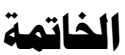

الحمدالله الأي أعانني على إتمام هذا البحث بفضل كرمه ومنه وجوده وقد

حاولت جاهداً أن أتم البحث دون إفراط أو تفربط مع ترتيب المادة علمياً منطقياً يسهل على القارئ فهم الموضوع واستيعابه وما خرجت به من هذا البحث يمكن تلخيصه بما يأتي:

أ - إن عموم البلوى من أهم أسباب التخفيف في الأحكام الشرعية إذ أنه يوجب تخفيف الحكم على الناس ودفع الحرج والضرر عنهم والضرر يزال عن المكلف الواحد فكيف إذا كان ضرراً عاماً لجميع المكلفين. r - - إن المتقدمين من العلماء لم يبحثوا عموم البلوى كمادة مستقلة بل إنهم لم ينصوا على تعريف منضبط له ولكنهم بحثوا صلة عموم البلوى بخبر الواحد حيث بحثوا هذه المسألة بحثاً مستفيضا ولكن دون الخوض في حقيقة عموم البلوى. r- - إن أسباب عموم البلوى في العموم ترجع الى أمرين هما: أ) أ عسر الاحتراز وذلك بأن الأمر يسيراً أو غزيراً بحيث الاحتراز عنه. ب) صعوبة الاستغناء وذلك بان يكون الناس في حاجة ماسة لهذا الأمر حتى إنهم لا يستطيعون تركه. ع - إن حالات عموم البلوى تتحقق في ثلاثة أنواع:

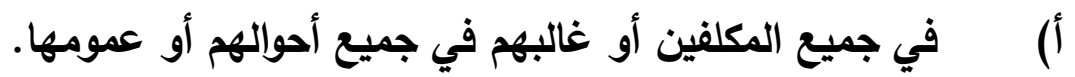
ب) في جميع المكلفين أو غالبهم في حال واحدة. ج) في المكلف الواحد في جميع أحواله او عمومها. 
ه - - إن العلماء المتقدمين قد عرفوا عموم البلوى بأسماء كثيرة بينوها في كتبهم وذلك كقولهم إن هذا أمر يعسر الاحتراز منه أو يعسر الاستغناء عنه أو إن فيه مشقة أو حرجا أو ضرورة وغير هذه العبارات مما هو موجود في كتبهم

צ- إن عموم البلوى يلعب دوراً أساسياً في علم أصول الفقه وذلك

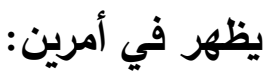
إن عموم البلوى قد يزيد أو ينقص في قوة بعض الأدلة الشرعية التي تستنبط منها الأحكام كما هو الحال في خبر الواحد وإجماع السكوتي. ب) إن عموم البلوى قد يكون سبباً لبعض الأدلة الأصولية وذلك كما في القياس والاستحسان وسد الأرائع وغيرها فان القياس قد يكون مبناه أمر عمت به البلوى وهكذا البقية. - - - إن عموم البلوى قد سبب خلاف كبير بين الفقهاء في كثير من الفروع الفقهية وكان سبباً في تباين الأحكام كما هو سبب في اختلاف الأصوليين في عدة مسائل له تعلق بها والاختلاف العميق الواقع بينهم في مسألة خبر الواحد خير دليل على ذلك. - - في زمانتا الحاضر هنالك مسائل كثيرة يلخل عموم البلوى في تطبيقاتها لأن هناك أمور مستجدة لا حصر لها قـ دخلت في حياتنا اليومية وعمت بها البلوى وأصح الناس لا يستغنون عنها. 9- - إن بعض الناس اليوم يفتون في الأمور المستجدة مستندين في فتواهم إلى عموم البلوى دون العلم بشروطه وهذا أمر يوقعهم بلا شك في 


\begin{tabular}{|c|c|}
\hline 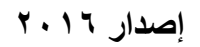 & حولية كلية اللراست الإسلاميةو العرييةبنين القاهرة العد (Tسا) \\
\hline
\end{tabular}

كثير من المحظورات الثرعية فلا بد من العلم بثروط عموم البلوى وتحققه في الواقعة قبل الإفتاء بها.

هذا ملخص ما توصلت إليه في هذا البحث سائلا الله تعالى أن يجعله خالصاً لوجهه الكريم وأن ينفعنا بما علمنا انه سميع مجيب ولا حول ولا قوة إلا بالله العلي العظيم. 


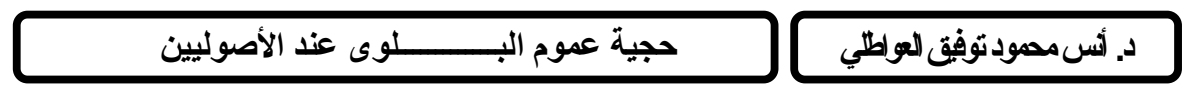

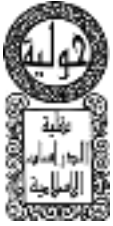




\section{المراجع}

$$
\begin{aligned}
& \text { 1- - القرءان الكريم. } \\
& \text { r - الحديث النبوي الثربف. }
\end{aligned}
$$

r- - تاج العروس للزبيدي / دار ليبيا للنشر والتوزبع بن غازي الطبعة

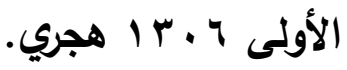

ـ - مجمل اللغة لأبي الحسين أحمد بن فارس اللغوي تحقيق زهير

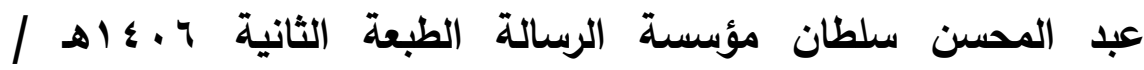
•) $9 \wedge 7$

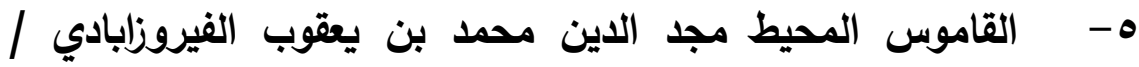
تحقيق مكتب تحقيق التراث في مؤسسة الرسالة. צ- - مختار الصحاح محمد بن ابي بكر الرازي ترتيب محمود خاطر بك

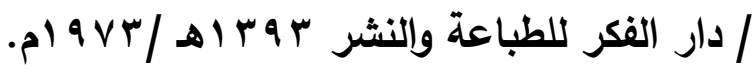
-V ومحمد النجار وحامد عبد القادر بإشراف عبد السلام هارون / الناشر دار إحياء التراث العربي بيروت لبنان.

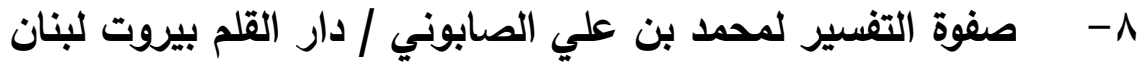

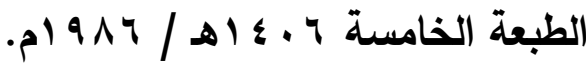
9- - الجامع الصحيح المختصر لمحمد بن إسماعيل البخاري / دار ابن

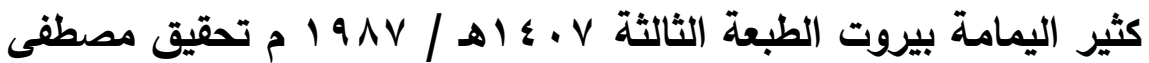
ديب. • - المعجم الكبير سليمان بن أحمد الطبراني / الناشر مكتبة العلوم

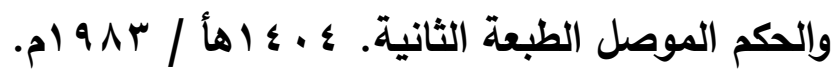


حجية عموم البـــــــــلـوى عند الأصوليين

د. أس محمود توفيق العولطي

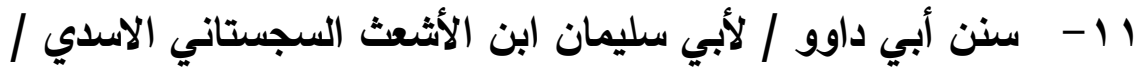
دار الفكر تحقيق محمد محي الدين عبد الحميد. r ا - السنن الكبرى لابي بكر محمد بن الحسين البيهقي / مكتبة دار

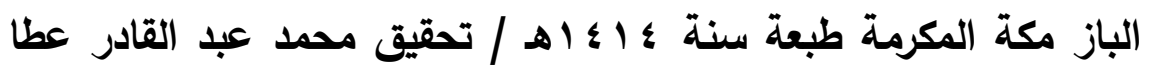
في عثرة أجزاء. با - سنن أبو ماجد لأبي عبدالله محمد يزيد القزويني تحقيق محمد فؤاد عبد الباقي ومذيلة بأحكام الألباني عليها / الناشر دار الفكر بيروت في جزئين. ـ ا - صيح ابن حيان لابي حاتم التميمي / مؤسسة الرسالة الطبعة

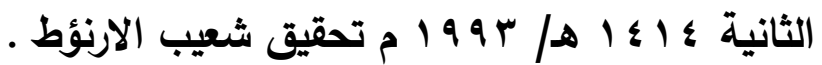
10 - سنن الترمذي لابو عيسى محمد بن عيسى الترمذي السلمي / الناشر دار إحياء التراث العربي بيروت تحقيق احمد محمد شاكر وآخرون ومذيلة بأحكام الألباني عليها. 17 - الرسالة للإمام محمد بن ادريسي الثافعي تحقيق عبد اللطيف الهميم وماهر ياسين الفحل / دار الكتب العلمي بيروت الطبعة الاولى سنة IV - أصول السرخسي لابي بكر محمد بن احمد السرخسي / دار الفكر

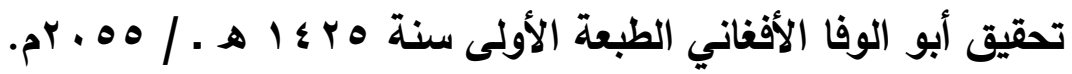
11 - شرح الكوكب المنير المسمى بمختصر التحرير للشيخ محمد بن احمد الفتوحي الحنبلي المعروف بان النجار تحقيق الدكتور محمد الزحيلي

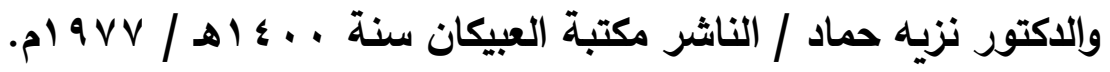


9 19 - المستصفى لعلم الأصول للإمام أبي حامد محمد بن محمد الغزالي / مكتب التحقيق بلار إحياء التراث العربي مؤسسة التاريخ العربي بيروت

\section{لبنان.}

• - الإحكام في أصول الأحكام لسيف الدين أبي الحسن علي بن محمد الامدي تخريج الثيخ إبراهيم العجوز / دار الكتب العلمية بيروت

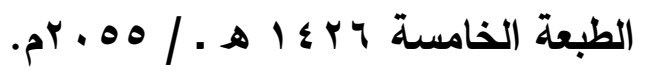

ا - - تقويم الأدلة في أصول الفقه للإمام أبي زيل عبيد الله بن عمر الدبوسي تحقيق خليل محيي الدين / دار الكتب العلمية بيروت الطبعة

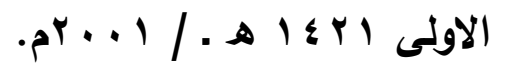

r r - تخريج الفروع على الأصول لثهاب الاين محمود بن احمد الزنجاني تحقيق محمد أديب الصالح / مكتبة العبيكان الطبعة الأولى

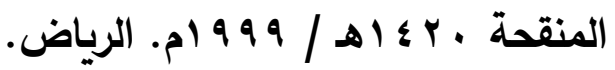

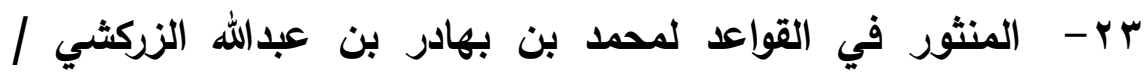
الناشر وزارة الأوقاف والثؤون الإسلامية في دولة الكويت الطبعة الثانية ه . ع ا هـ تحقيق الدكتور تيسير فائق احمد. § - - الكافي في فقه الإمام المبجل احمد ابن حنبل لعبدالله بن قدامة المقدسي مطبوع في أربعة أجزاء . هץ - الاختيار لتعليل المختار لعبداله بن محمود الموصلي الحنفي تحقيق عبد اللطيف محمد عبد الرحمن / الناشر دار الكتب العلمية الطبعة

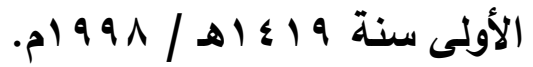
צr - إرشاد الفحول إلى تحقيق من علم الأصول لمحمد بن علي الثوكاني تحقيق محمد صبحي بن حسن حلاق / دار ابن كثير الطبعة

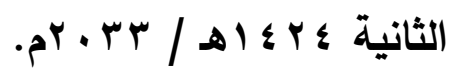




\section{حجية عموم البـــــــلـوى عند الأصوليين}

دـ أس محود توفيق العواطي

- FV - علم أصول الفقه للاكتور عبد الوهاب خلاف / دار الحديث القاهرة

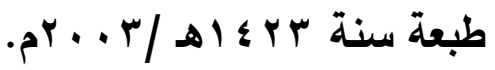
^r - اثر الاختلاف في القواعد الأصولية في اختلاف الفقهاء دكتور

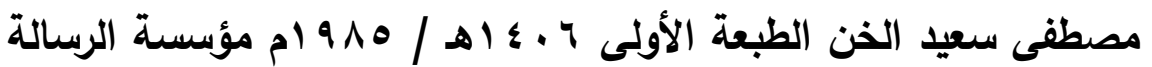

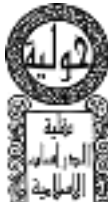
والطباعة والنشر بيروت.

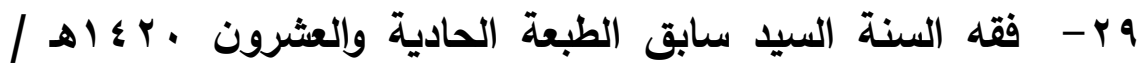
. 9 ام ادار الفتح للإعلام العربي القاهرة.

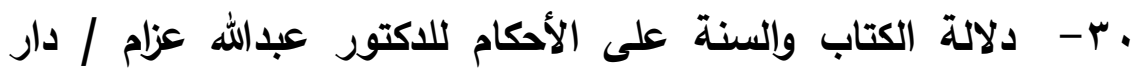
المجتمع للنشر والتوزيع الطبعة الأولى سنة ء ـ . ب م. اس- عموم البلوى لمسلم بن محمد بن ماجد الدوسري / مكتبة الرشد

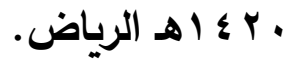
r r- الموسوعة الفقهية الكويتية / الناشر وزارة الأوقاف والثؤون الإسلامية في دولة الكويت الطبعة الجديدة سنة ؟ ـ . ب م. rr- فاستقم كما أمرت / بحث منشور لفضيلة الثيخ عبد العزيز بن

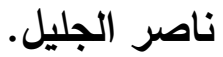

